Cornell University Law School Scholarship@Cornell Law: A Digital Repository

\title{
Damages versus Specific Performance: Lessons from Commercial Contracts
}

Theodore Eisenberg

Cornell Law School (deceased)

Geoffrey P. Miller

New York University, geoffrey.miller@nyu.edu

Follow this and additional works at: https://scholarship.law.cornell.edu/facpub

Part of the Business Organizations Law Commons, $\underline{\text { Contracts Commons, and the Legal }}$ Remedies Commons

\section{Recommended Citation}

Eisenberg, Theodore and Miller, Geoffrey P., "Damages versus Specific Performance: Lessons from Commercial Contracts," 12 Journal of Empirical Legal Studies 29-69 (2015)

This Article is brought to you for free and open access by the Faculty Scholarship at Scholarship@Cornell Law: A Digital Repository. It has been accepted for inclusion in Cornell Law Faculty Publications by an authorized administrator of Scholarship@Cornell Law: A Digital Repository. For more information, please contact jmp8@cornell.edu. 


\title{
Damages Versus Specific Performance: Lessons from Commercial Contracts
}

\author{
Theodore Eisenberg and Geoffrey P. Miller*
}

\begin{abstract}
Specific performance is a central contractual remedy but, in Anglo-American law, generally is subordinate to damages. Despite rich theoretical discussions of specific performance, little is known about parties' treatment of the remedy in their contracts. We study 2,347 contracts of public corporations to quantify the presence or absence of specific performance clauses in several types of contracts. Although a majority of contracts do not refer to specific performance, substantial variation exists in the rates of including specific performance clauses. High rates of specific performance use in the area of corporate combinations through merger (53.4 percent) or assets sales (45.1 percent), inclusion of specific performance in some contracts of every type, and much lower use of it in loan agreements suggest that treatment of specific performance in sophisticated corporate contracts is more complex than existing theories of contractual remedies allow. Theories should expressly account for contract type variation. We also present results on the associations among contractual acceptance of five default dispute resolution rules: specific performance clauses, arbitration clauses, jury trial waiver clauses, litigation forum clauses, and attorney fee clauses. Rejecting the default damages rule in favor of specific performance is associated with rejecting each of the four other dispute resolution clauses.
\end{abstract}

\section{INTRODUCTION}

Black-letter law holds that an injunction-specific performance-is available in an action for breach of contract only in cases where damages are inadequate. ${ }^{1}$ This rule has a hoary lineage, with antecedents in the early common law of England. ${ }^{2}$ It is endorsed by courts

\footnotetext{
* The late Theodore Eisenberg was Henry Allen Mark Professor of Law and Adjunct Professor of Statistical Science Cornell University. Miller is Stuyvesant P. Comfort Professor of Law, New York University. Miller can be contacted at geoffrey.miller@nyu.edu.

We thank Natalie Erbe, Felicity S. Kohn, Jeremy Masys, Sergio Muro, Hillel Pohulanik, Whitney Schwab, Peter Van Valkenburgh, and Cathy Weist for valuable research assistance.
}

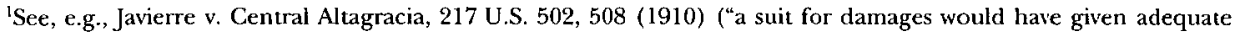
relief, and therefore the appellee should have been confined to its remedy at law"); William Bishop, The Choice of Remedy for Breach of Contract, 14 J. Legal Stud. 299 (1985); Lewis Kornhauser, An Introduction to the Economic Analysis of Contract Remedies, 57 U. Colo. L. Rev. 683 (1986); Anthony T. Kronman, Specific Performance, 45 U. Chi. L. Rev. 351 (1978).

"See Michael J. Sechler, Supply Versus Demand for Efficient Legal Rules: Evidence from Early English "Contract" Law and the Rise of Assumpsit, 73 U. Pitt. L. Rev. 161 (2011). 
throughout the United States and elsewhere in the English-speaking world. The subordination of specific performance is firmly embedded in the jurisprudence of contract law, and generally accepted in the courts.

Yet the rule preferring damages over specific performance is also mysterious. Its intellectual underpinnings are far from clear-as evidenced by a vigorous debate among contract theorists regarding the utility of the rule. ${ }^{3}$ The black-letter law of many countries with modern systems of contract law does not prefer damages over specific performance. ${ }^{4}$ Even in the United States, long a citadel of support for the rule, the foundations appear to be eroding; courts do not always adhere rigidly to the rule, ${ }^{5}$ and some have argued that the measure of damages actually awarded is closer to the breaching party's profit from breach than to the nonbreaching party's lost profits-a measure that emulates, in some respects, the supposedly disfavored specific performance remedy. ${ }^{6}$

This article studies the rule on specific performance from a different perspective than those employed previously. Instead of theorizing about the rule, we examine the actual behavior of contracting parties. ${ }^{7}$ Specifically, we analyze a data set of 2,347 contracts filed as exhibits with the Securities and Exchange Commission (SEC) in connection with reports of material events by reporting companies on Form 8-K, the "current report" form companies must file with the SEC to announce major events of which shareholders should be aware.

${ }^{9}$ See Richard Posner, Let Us Never Blame a Contract Breaker, 107 Mich. L. Rev. 1349, 1361 (2008) (endorsing the traditional rule but recognizing that the arguments for and against the rule are "not conclusive"); see also sources cited in notes 14-43 infra.

${ }^{4}$ See Gerard De Vries, Right to Specific Performance: Is There a Divergence Between Civil- and Common-Law Systems and, If So, How Has it Been Bridged in the DCFR? 17 Eur. Rev. Private L. 581 (2009); Ronald J. Scalise Jr., Why No "Efficient Breach" in the Civil Law?: A Comparative Assessment of the Doctrine of Efficient Breach of Contract, 55 Am. J. Comp. L. 721, 726-33 (2007); Henrik Lando \& Caspar Rose, On the Enforcement of Specific Performance in Civil Law Countries, 24 Int'l Rev. L. \& Econ. 473 (2004); John P. Dawson, Specific Performance in France and Germany, 57 Mich. L. Rev. 495, 496 (1958). However, the differences between civil- and common-law systems are not always as clear-cut as might at first appear. See note 45 and accompanying text infra.

${ }^{5}$ See notes $32-43$ and accompanying text infra.

${ }^{6}$ See Steve Thel \& Peter Siegelman, You Do Have to Keep Your Promises: A Disgorgement Theory of Contract Remedies, 52 William \& Mary L. Rev. 1181, 1184 (2011).

${ }^{7}$ We have developed this approach to legal theory-that is, examining the actual behavior of sophisticated contracting parties whose incentives ex ante are to maximize the joint value of the undertaking-in several prior papers dealing with other issues of contractual dispute resolution. See Theodore Eisenberg \& Geoffrey P. Miller, The English vs. the American Rule on Attorney Fees: An Empirical Study of Public Company Contracts, 98 Cornell L. Rev. 327 (2013); Theodore Eisenberg \& Geoffrey P. Miller, The Flight to New York: An Empirical Study of Choice of Law and Choice of Forum Clauses in Publicly-Held Companies' Contracts, 30 Cardozo L. Rev. 1475 (2009); Theodore Eisenberg, Geoffrey P. Miller \& Emily Sherwin, Mandatory Arbitration for Customers But Not for Peers, 92 Judicature 118 (2009); Theodore Eisenberg, Geoffrey P. Miller \& Emily Sherwin, Arbitration's Summer Soldiers: An Empirical Study of Arbitration Clauses in Consumer and Non-Consumer Contracts, 41 U. Mich. J. L. Reform 871 (2008); Theodore Eisenberg \& Geoffrey P. Miller, Do Juries Add Value? Evidence from an Empirical Study of Jury Trial Waiver Clauses in Large Corporate Contracts, 4 J. Empirical Legal Stud. 539 (2007); Theodore Eisenberg \& Geoffrey P. Miller, The Flight from Arbitration: An Empirical Study of Ex Ante Arbitration Clauses in Publicly-Held Companies' Contracts, 56 DePaul L. Rev. 335 (2007); Theodore Eisenberg \& Geoffrey Miller, Ex Ante Choices of Law and Forum: An Empirical Analysis of Corporate Merger Agreements, 59 Vanderbilt L. Rev. 1975 (2006). 
This data set offers the advantage that it contains important contracts entered into by sophisticated economic actors whose incentives are to agree to rules that generate joint value for the transaction. Because of these features, there is reason to believe that the contract terms observed in this data set reflect efficient solutions to the contracting problem.

We examine the contracts in this data set to identify and analyze efforts by the counterparties to contract around the traditional rule preferring damages over specific performance. ${ }^{8}$ If nothing is said in the contract about this issue, the ordinary background rule of contract law will apply, but the parties can attempt to avoid the application of this rule by including language that seeks to influence how a court will treat the choice among contract remedies-for example, by stipulating that damages are not an adequate remedy for breach and agreeing that specific performance is appropriate. Although it is not clear that this language will be binding on the courts ${ }^{9}$ the parties' ex ante agreement on this point will surely have an influence, perhaps a decisive influence, on how a court rules in an actual dispute. ${ }^{10}$ Thus, clauses providing for specific performance have the potential to cause a court that would otherwise award damages to award specific performance instead.

Our reason for studying these clauses is that sophisticated parties' contractual silence concerning specific performance suggests that they do not have strong objections to damages as the preferred remedy in the event of breach-and have adjusted other contract terms (such as price) to account for the relative impacts of a damages regime on their expected payoffs from the deal. ${ }^{11}$ Parties concerned about contractual silence's negative inference concerning the availability of specific performance can expressly negate the inference. For example, an asset sale agreement states that conditions authorizing termination of an agreement shall not be deemed "to impair the right of any party to compel specific performance by another party of its obligations under this Agreement."12

\footnotetext{
${ }^{8}$ On contracting around background remedies for breach of contract, see Alan Schwartz, The Myth that Promisees Prefer Supercompensatory Remedies: An Analysis of Contracting for Damage Measures, 100 Yale L.J. 369, 387-89 (1990).
}

\footnotetext{
${ }^{9}$ Compare Ash Park, LLC v. Alexander \& Bishop, Ltd., 324 Wis.2d 703, 724, 783 N.W.2d 294, 303 (Wis. 2010) ("when a contract specifies remedies available for breach of contract, the intention of the parties generally governs") with Stokes v. Moore, 262 Ala. 59, 64 (Ala. 1955) (parties cannot determine the availability of equitable relief on their own).

${ }^{10}$ See Stokes v. Moore, $262 \mathrm{Ala} .59,64$ (Ala. 1955) ("the provision for an injunction is important in its influence upon an exercise of the discretionary power of the court to grant a temporary injunction").

"See Daniel Markovits \& Alan Schwartz, The Myth of Efficient Breach: New Defenses of the Expectation Interest, 97 Va. L. Rev. 1939 (2011) (suggesting that sophisticated parties who enter a contract under the traditional rule are aware that they are buying or selling an option to perform or pay damages); Daniel Markovits \& Alan Schwartz, The Expectation Remedy and the Promissory Basis of Contract: Symposium in Honor of the 30th Anniversary of the Publication of Contract as Promise, 45 Suffolk U. L. Rev. 799, 808 (2012).
}

${ }^{12}$ Asset Purchase Agreement dated as of Oct. 17, 2001 between Imation and KPG $§ 10.02(c)$. 
The inference of the acceptability of damages, of course, is not true by necessity; possibly the observed behavior of contracting parties on the question of remedies reflects inattention, complacency, or a simple lack of imagination. However, given the sophistication of the parties in our data set, the importance of the contracts involved, and the fact that many of these contracts contain other clauses governing disputes under the contract, it is plausible to suppose that the parties' silence on the matter of contract remedies usually is meaningful. When, on the other hand, the parties have attempted to opt out of damages relief and into the specific performance remedy, it can be inferred that their judgment is that the value of the contract ex ante will be maximized if the courts will award specific performance in the event of breach rather than awarding contract damages. Thus, it is useful to study cases where parties have specifically expressed a preference for specific performance as a remedy, since we can infer from their behavior that they believe that specific performance is the remedy that maximizes joint profits ex ante. This article performs such a study.

In brief, our study supports the inference that sophisticated contracting parties often do prefer specific performance to contract damages and they prefer it a majority of the time in contracts involving corporate combinations. Thus, while a majority of contracts, 68.5 percent, ${ }^{13}$ do not refer to specific performance, substantial variation exists in the rates of including specific performance clauses. High rates of specific performance use in the area of corporate combinations through merger (53.4 percent) or assets sales (45.1 percent), inclusion of specific performance in some contracts of every type, and much lower use of it in loan agreements suggest that theories of contractual remedy should expressly account for contract type variation. Analysis of other variables reveals that specific performance is not strongly correlated with the presence of a non-U.S. party to a contract and is associated with relational contracts (but this result is sensitive to specific types). Inclusion of specific performance clauses is significantly associated with the presence of other contract terms departing from default dispute resolution clause treatment.

This article is structured as follows. Section II sets forth the traditional rule and explores the arguments for and against its efficiency as compared with specific performance. Section III outlines the prior empirical literature. Section IV describes the data set and sets forth the hypotheses we test. Section V analyzes the results and Section VI concludes.

\section{Arguments For and Against Specific Performance}

\section{A. The Traditional Rule}

As noted, the traditional common-law rule is that specific performance is available only when damages are inadequate. The rule is an instance of the more general principle that

\footnotetext{
${ }^{13}$ This falls to 53.6 percent if one regards underwriting contracts that effectively, but not expressly, provide for specific performance as preferring specific performance. See text accompanying notes 77-79, 95 infra.
} 
equitable relief-specific performance being an equitable remedy ${ }^{14}$-is awarded only when the legal remedy is inadequate. ${ }^{15}$

This leaves open the question of when damages are "inadequate." This condition occurs when damages are difficult to quantify-for example, during the sale of a business with no ready market value, ${ }^{16}$ or when the breach would prevent the nonbreaching party from performing a contract with a third party-as when the nonbreaching party is under a contractual obligation to resell the specific property in question. ${ }^{17}$ Damages can also be inadequate when the plaintiff has a particular use for the property that cannot be fully compensated by a damage award based on market value. ${ }^{18}$ Courts may in their discretion conclude that damages are inadequate in other settings as well.

Despite its widespread adoption and hoary lineage, the traditional rule of AngloAmerican jurisprudence-a rule that we will sometimes refer to as the "damages" rule-is today a controversial issue in contract theory. The next section sets out some of the leading arguments for and against the traditional rule.

\section{B. Arguments in Favor of the Traditional Rule}

Several justifications can be imagined for the Anglo-American rule, at least as a default principle that most contracting parties would prefer. ${ }^{19}$

1. Damages, it is said, are generally a more efficient remedy because they permit either party to engage in efficient breaches of contract-that is, to breach the contract when the social value of breaching exceeds the social cost. If one party will gain more from breaching than the other will lose from the breach, then the first party can breach the contract and pay the second party damages equal to the latter's lost profits. The first party is better off as a result of the breach and the second is no worse off; society as a whole is a beneficiary. Specific performance, on

\footnotetext{
${ }^{14}$ See, e.g., Lewis v. Premium Inv. Corp., 351 S.C. 167, 568 S.E.2d 361 (2002); Ellis v. Stanford, 256 Ga. App. 294, 568 S.E.2d 157 (2002); Schreck v. T \& C Sanderson Farms, Inc., 37 P.3d 510 (Colo. Ct. App. 2001); Webster v. Aust, 628 So. 2d 846 (Ala. Civ. App. 1993); Sayer v. Bowley, 243 Neb. 801, 503 N.W.2d 166 (1993).
}

${ }^{15}$ See Douglas Laycock, Modern American Remedies: Cases and Materials (4th ed. 2010) at 380 ("It is hornbook law that equity will not act if there is an adequate remedy at law.").

${ }^{16}$ See, e.g., Medcom Holding Co. v. Baxter Travenol Labs., Inc., 984 F.2d 223, 227 (7th Cir.1993).
${ }^{17}$ See, e.g., Texaco v. Creel, 310 N.C. 695,314 S.E.2d 506, 512 (1984).

${ }^{18}$ See, e.g., Curtice Bros. Co. v. Catts, 72 N.J. Eq. 831, 66 A. 935 (Chancery 1907) (irreparable injury results from the inability to procure at any price the goods necessary to assure the successful operation of a plant).

\footnotetext{
${ }^{19}$ For defenses of the traditional rule, see, e.g., Avery Katz, Virtue Ethics and Efficient Breach, in SymposiumContract as Promise at 30: The Future of Contract Theory, 45 Suffolk U. L. Rev. 777, 784-85 (2012) (expectation damages may be justifiable as a default rule providing the remedy that most parties would prefer, and that, in a world of costless and complete contracting, they would have explicitly chosen); Timothy Muris, The Costs of Freely Granting Specific Performance, Duke L.J. 1053 (1982); Edward Yorio, In Defense of Money Damages for Breach of Contract, 82 Colum. L. Rev. 1365 (1982).
} 
the other hand, does not promote efficient breaches in the same way. Because under specific performance the nonbreaching party can compel the breaching party to perform its obligations under the contract, the social value of the breach is lost. ${ }^{20}$ Settlement bargaining will overcome this problem if transactions costs are low enough. ${ }^{21}$ The breaching party can pay the nonbreaching party some amount larger than the breaching party's damages but lower than the breaching party's profit from breach, leaving both parties better off and generating the socially efficient allocation of resources. However, sometimes, costs of transactions-such as strategic behavior of the parties, miscalculations, emotional factors, or simply a lack of time to bargain-can prevent the parties from engaging in this sort of value-enhancing deal. ${ }^{22}$ In such cases, society can be worse off under specific performance than under damages.

2. The rule preferring damages over specific performance might limit the parties' ability to extract unfair consideration during settlement negotiations. ${ }^{23}$ Suppose that the plaintiff's damages from breach are $\$ 500,000$ but performing the contract would cost the defendant $\$ 600,000$. If it is presumed that the plaintiff's purpose in entering the contract is only to obtain the profits expected from the defendant's performance, rather than to also obtain extra profits after breach, then the injunctive remedy would allow the plaintiff to obtain up to $\$ 100,000$ in unbargained-for compensation from the defendant as the price for settling the suit. The rule limiting specific performance to cases where damages are inadequate polices against this sort of opportunism. ${ }^{24}$ At the same time, the rule may also limit the defendant's ability to behave opportunistically in some settings. Suppose that the contract is one for personal services. If the preferred remedy were injunctive relief, then the defendant could satisfy its obligation by performing the services in question. However, since relations between the parties have broken down at this point, the defendant can elect to shirk on performance in order to reduce its costs of complying with the judgment. The Anglo-American rule protects plaintiffs against this risk by preferring a monetary remedy-thus

\footnotetext{
${ }^{20}$ See Paul G. Mahoney, Contract Remedies: General, in 3 Encyclopedia of Law and Economics 117, 125-26 (Boudewijn Bouckaert \& Gerrit De Geest eds., 2000).

${ }^{21}$ See Northern Ind. Pub. Serv. Co. v. Carbon Cty. Coal Co.,799 F.2d 265, 279 (7th Cir. 1986).

${ }^{22}$ See Ward Farnsworth, Do Parties to Nuisance Cases Bargain After Judgment? A Glimpse Inside the Cathedral, 66 U. Chi. L. Rev. 373, 381-83 (1999) (finding in a study of tort cases that the parties often failed to bargain for a monetary settlement after the issuance of injunctive relief).
}

${ }^{23}$ See generally Ian Ayres \& Kristin Madison, Threatening Inefficient Performance of Injunctions and Contracts, 148 U. Pa. L. Rev. 45 (1999); Walgreen Co. v. Sara Creek Prop. Co., 966 F.2d 273, 274-75 (7th Cir. 1992) (Posner, J.).

\footnotetext{
${ }^{24}$ See Northern Ind. Pub. Serv. Co. v. Carbon Cty. Coal Co.,799 F.2d 265, 279-80 (7th Cir. 1986) ("Carbon County is [probably] seeking specific performance in order to have bargaining leverage with NIPSCO, and we can think of no reason why the law should give it such leverage"); Foster v. American Mach. \& Foundry Co., 492 F.2d 1317, 1324 (2d Cir. 1974) (stating that an injunction prohibiting infringement "is not intended as a club to be wielded by a patentee to enhance his negotiating stance").
} 
allowing the plaintiff to find another service provider to carry out the contract obligations.

3. The rule could be seen to police against destructive behaviors by litigants who are so emotionally involved in the litigation that they seek specific performance for reasons of spite-not to benefit themselves, but rather to harm their adversaries. ${ }^{25}$

4. The rule could be seen as enhancing the right to jury trial, since it establishes a preference for damages (which trigger a right to jury trial) over injunctive relief (generally adjudicated by the court).

5. The rule might conserve on judicial resources to the extent that the burden on courts of ascertaining the correct measure of damages is lower than the burden of policing the defendant's performance of the contract.

6. The rule might be justified as a tiebreaker: since some remedy must be awarded, and it would not be appropriate to award both, ${ }^{26}$ courts need a principle for deciding which one to award. The Anglo-American rule (in theory) partitions the remedy into two mutually exclusive categories: cases where damages are adequate, in which case money is the exclusive remedy; and cases where damages are not adequate, in which case specific performance is the exclusive remedy.

7. The rule might be justified simply because it would be too disruptive to change it, given that millions of contracts are written under the assumption that the rule will govern their enforcement. ${ }^{27}$

8. A preference for damages over specific performance might be justified from a moral point of view. This argument must overcome the difficulty that damages appear, from one point of view, to endorse the morally questionably act of breaking a promise. The damages remedy, however, could be conceived of not as an option to breach a promise, but as an alternative form of performing a contractual obligation; in this view, the morally problematic idea of the law rewarding people for breaking promises disappears because no promise is broken. ${ }^{28}$ Backing this interpretation is the idea that because people in contractual relationships implicitly promise to act in a way that maximizes their joint welfare, the law does not unduly interfere with autonomy when it permits a party to an incomplete contract

\footnotetext{
${ }^{25}$ See Brandon Grinsted, Comment, The Evolution of Court-Ordered Mergers: An Equitable Remedy or a Marriage Made in Hell? 53 Mercer L. Rev. 1647, 1672 (2002); Jordan A. Goldstein, The Efficiency of Specific Performance in Stock-for-Stock Mergers, 29 Delaware J. Corp. L. 747, 760 n.61 (2004).
}

${ }^{26}$ See Bronson v. La Crosse \& Milwaukee R.R., 68 U.S. 405, 409-10 (1863); Price v. Franklin Inv. Co., 574 F.2d 594, 597 (D.C.Cir.1978).

${ }^{27}$ See Posner, supra note 3 , at 1361.

${ }^{28}$ See, e.g., Richard R.W. Brooks, The Efficient Performance Hypothesis, 116 Yale L.J. 568 (2006); Charles J. Goetz \& Robert E. Scott, Liquidated Damages, Penalties and the Just Compensation Principle: Some Notes on an Enforcement Model and a Theory of Efficient Breach, 77 Colum. L. Rev. 554, 558 (1977); Markovits \& Schwartz, The Myth of Efficient Breach, supra note 11; Markovits \& Schwartz, The Expectation Remedy, supra note 11; David Simon \& Gerald A. Novack, Limiting the Buyer's Market Damages to Lost Profits: A Challenge to the Enforceability of Market Contracts, 92 Harv. L. Rev. 1395, 1436-37 (1979). 
to avoid performance by paying damages. ${ }^{29}$ Meanwhile, an order to pay damages can be seen as less intrusive on the liberty of the breaching party than an order requiring that party to perform the contract. ${ }^{30}$

\section{Arguments Against the Traditional Rule}

The foregoing arguments support the rule favoring contract damages over specific performance. On the other hand, other considerations suggest that specific performance ought to be the favored remedy, or at least that the law ought to favor neither remedy, ${ }^{31}$ leaving the nonbreaching party with the option about which to seek in a given case. These arguments include the following.

1. Specific performance might be preferred if courts frequently make errors as to the measure of contract damages. ${ }^{32}$ The rule favoring contract damages takes this consideration into account, to a degree, by recognizing that uncertainty in the estimation of damages is one reason to conclude that the damages remedy is inadequate. But, in general, courts apply this exception in cases where damages are obviously difficult or impossible to quantify-as in the case of the sale of a small or new business with no market comparables. ${ }^{33}$ If, however, courts miscalculate contract damages in a wider range of cases, then specific performance may generate more accurate outcomes from a social point of view. ${ }^{34}$ The problem is particularly acute if courts err systematically in measuring damages, for example, by excluding incidental damages. ${ }^{35}$ If the error bias is systematic, the result will

\footnotetext{
${ }^{29}$ See Louis Kaplow \& Steven Shavell, Fairness Versus Welfare 172-213 (2002); Steven Shavell, Why Breach of Contract May Not Be Immoral Given the Incompleteness of Contracts, 107 Mich. L. Rev. 1569 (2009).

${ }^{30}$ See Brian Bix, Theories of Contract Law and Enforcing Promissory Morality: Comments on Charles Fried, in Symposium-Contract as Promise at 30: The Future of Contract Theory, 45 Suffolk U. L. Rev. 719, 730 (2012).

${ }^{91}$ This was the view of Justice Story. Melville M. Bigelow, 2 Commentaries on Equity Jurisprudence as Administered in England and America by Joseph Story $\$ 717$ a (13th ed.); Curtice Bros. Co. v. Catts, 72 N.J. Eq. 831,66 A. 935 (Chancery 1907) (citing Story).
}

${ }^{32}$ See Steven Shavell, Damage Measures for Breach of Contract, 11 Bell J. Econ. 466, $488-89$ (1980). See also Eric Posner, A Theory of Contract Law Under Conditions of Radical Judicial Error 1 (U. Chi. Law School, John M. Olin Law \& Economics Working Paper No. 80), available at <http://papers.ssrn.com/sol3/papers.cfm?abstract _id=173788> (arguing that judges are incapable of accurately assessing either liability or damages in contract cases).

${ }^{33}$ See, e.g., Evergreen Amusement Corp. v. Milstead, 112 A.2d 901 (Md. 1955) (loss of profits from a new business may not be recovered because they are speculative).

${ }^{94}$ See, e.g., Bishop, supra note 1 , at 300 (judicial underestimation of damages may generate inefficient levels of breach).

${ }^{35}$ See Melvin A. Eisenberg, Actual and Virtual Specific Performance, the Theory of Efficient Breach, and the Indifference Principle in Contract Law, 93 Cal. L. Rev. 975 (2005); Richard Craswell, Contract Remedies, Renegotiation, and the Theory of Efficient Breach, 61 S. Cal. L. Rev. 629, 662 (1988); Alan Schwartz, The Case for Specific Performance, 89 Yale L.J. 271, 276 (1979). 
increase the frequency of inefficient breaches because parties who are deciding whether to breach their promises anticipate that they will not have to pay full compensatory damages if they do breach. Especially if the inefficiencies of holding parties to inefficient terms are often corrected in settlement bargaining, the factor of judicial error may favor specific performance over damages.

2. Specific performance may enhance efficiency to the extent that it respects and enforces the ex ante agreement of the parties. ${ }^{36}$ If at the time of contract the parties have superior information, or superior analytical skills, than courts can bring to bear in ex post breach of contract litigation, then, all else equal, it could be more efficient to require the parties to perform their obligations. ${ }^{37}$

3. Specific performance may also enhance efficiency by assuring nonbreaching parties ex post power to decide what remedy is preferable. This avoids the need to expend time and effort to anticipate what the ex post situation may be at the time of contracting. For example, an indenture contract may provide that, in the event of default, the indenture trustee may enforce rights by any method the trustee chooses "whether for the specific enforcement of any covenant or agreement in this Indenture or in aid of the exercise of any power granted herein, or to enforce any other proper remedy or legal or equitable right vested in the Indenture Trustee by this Indenture or by law." ${ }^{8}$

4. Specific performance might be preferable from a moral point of view. ${ }^{39}$ If we accept the ethical premise that people ought to keep their promises, then it would seem that the law should hold the breaching party to his or her promise. The nonbreaching party did not promise to pay the breaching party damages; he or she promised to perform the contract as agreed. Thus, according to this argument, the courts ought to award specific performance as a matter of course, unless good reasons are presented to prefer the damages remedy. ${ }^{40}$

\footnotetext{
${ }^{36}$ See Thomas S. Ulen, Specific Performance, in 3 New Palgrave Dictionary of Economics and the Law 481, 482 (Peter Newman ed., 1998); Thomas S. Ulen, The Efficiency of Specific Performance: Toward a Unified Theory of Contract Remedies, 83 Mich. L. Rev. 341 (1984).
}

${ }^{37}$ See Schwartz, supra note 35, at 291-92.

${ }^{87}$ E.g., Master Indenture Between First Consumers Credit Card Master Note Trust, Issuer, and the Bank of New York, Indenture Trustee, Dated as of Mar. 1, 2001, amended and restated as of Dec. 31, 2001, at 30.

${ }^{30}$ See, e.g., Charles Fried, Contract as Promise: A Theory of Contractual Obligation 16 (1981); Randy E. Barnett, Contract Remedies and Inalienable Rights, 4 Soc. Phil. \& Pol'y 179, 180, 183 (1986); Daniel Friedmann, The Efficient Breach Fallacy, 18 J. Legal Stud. 1, 13-14 (1989); Daniel Friedmann, Economic Aspects of Damages and Specific Performance Compared, in Contract Damages: Domestic and International Perspectives 65 (Ralph Cunnington \& Djakhongir Saidov eds., 2008); Peter Linzer, On the Amorality of Contract Remedies-Efficiency, Equity, and the Second Restatement, 81 Colum. L. Rev. 111, 138 (1981).

${ }^{40}$ See Seana Valentine Shiffrin, The Divergence of Contract and Promise, 120 Harv. L. Rev. 708, 722-23 (2007); Jody S. Kraus, The Correspondence of Contract and Promise, 109 Colum. L. Rev, 1603 (2009); Andrew S. Gold, A Moral Rights Theory of Private Law, 52 William \& Mary L. Rev. 1873, 1924-25 (2011). 
5. Specific performance might be preferred on the ground that it rewards and enforces the socially valuable investments that contracting parties make in their relationship with one another. If people could casually walk away from contractual commitments simply by paying money, they and their counterparties have less of an incentive to invest in the relationship in the first place-much as Donald Trump may find it easier to terminate a marriage when he has an iron-clad prenuptial agreement in place that allows him to exit in exchange for some specified monetary compensation. ${ }^{41}$

6. Specific performance might be preferred because it honors and encourages norms of fidelity and trust in commercial settings. If one believes that these social norms are inherently valuable, and believes further that the damages rule encourages the breakdown of these norms by validating the commoditization of commercial relationships, then specific performance might be preferred because it honors and enhances norms of social solidarity. ${ }^{42}$

7. Perhaps specific performance should be preferred because the preference for damages favors sophisticated parties, who are better able to determine whether to perform or breach and pay damages. If the law in general should avoid favoring more sophisticated parties, then perhaps it should prefer specific performance to damages when the contract is breached. ${ }^{43}$

\section{Prior Empirical Literature}

Prior empirical literature on contract enforcement falls into two broad categories: comparative studies of contract enforcement across legal systems and experimental or statistically-based studies of particular contracting issues.

\section{A. Comparative Analysis}

Although it was once conventional wisdom that civil-law systems endorse specific performance as the preferred remedy, or at least allow the nonbreaching party to select the remedy, ${ }^{44}$ the trend of modern research is to downplay the differences between civil- and common-law systems. When performance of pecuniary obligations is demanded, most

\footnotetext{
${ }^{41}$ See Katz, supra note 19, at 792 (exploring but not endorsing the idea that "from an efficiency perspective, sacrificing some degree of efficient reallocation of resources ex post could be economically worthwhile in order to achieve more efficient investment incentives ex ante; this is a consequentialist reason for commitment that might lead some or even most parties to prefer specific performance over expectation protection").

${ }^{42}$ See id. at 794-95 ("those who are committed to the virtues of solidarity and trust, and concerned about their possible decline in modern society, may have reason to object to establishing a default rule of pay-or-perform, and to oppose a legal theory that promotes such a rule as socially desirable").
}

${ }^{43}$ See Gregory Klass, To Perform or Pay Damages, 98 Va. L. Rev. 143, 146 (2012).

${ }^{44}$ See, e.g., Charles Szladits, The Concept of Specific Performance in Civil Law, 4 Am. J. of Comp L. 208 (1955). 
civil-law courts will grant the specific performance remedy. ${ }^{45}$ The same, however, is effectively true in common-law countries, since in the case of pecuniary obligations an order to perform the contract can be indistinguishable from an order to pay damages (if the defendant has a legally proven past-due obligation to pay the plaintiff money, the courts in both common-law and civil-law countries will order him or her to pay up). Even in the case of nonpecuniary obligations, differences between civil- and common-law countries may be smaller than at first appears. Even though civil-law systems endorse specific performance, courts in some of these systems appear to administer rules in actual practice that are not dramatically different than the rules applied in common-law systems. ${ }^{46}$ Some civil-law countries purport to grant specific performance even if there are readily available substitutes for performance, ${ }^{47}$ although such relief may be granted only in limited circumstances. ${ }^{48}$ In other countries, however, courts may restrict the remedy of specific performance when a substitute for performance is available: Denmark, ${ }^{49}$ Germany, ${ }^{50}$ Sweden, ${ }^{51}$ Italy, ${ }^{52}$ Denmark, ${ }^{53}$ and China ${ }^{54}$ are examples. In this latter group of countries, the rules on contract enforcement converge substantially with those applicable in the United States.

${ }^{45}$ See De Vries, supra note 4.

${ }^{46}$ Posner, supra note 3, at 1362-63 (courts "exercise discretion to award damages rather than order specific performance, and often the same outcomes are reached in common law and civil law systems under different doctrinal rubrics"); Wayne R. Barnes, Contemplating a Civil Law Paradigm for a Future International Commercial Code, 65 La. L. Rev. 677, 751-52 (2005); John Y. Gotanda, Recovering Lost Profits in International Disputes, 36 Georgetown J. Int'l L. 61, 63-64 (2004); Julian Hermida, Convergence of Civil Law and Common Law in the Criminal Theory Realm, 13 U. Miami Int'l \& Comp. L. Rev. 163, 167-70 (2005); Patricia Pattison \& Daniel Herron, The Mountains are High and the Emperor is Far Away: Sanctity of Contract in China, 40 Am. Bus. L.J. 459, 475 (2003).

${ }^{47}$ France and Switzerland are examples. See Lando \& Rose, supra note 4, at 478 (France); James Beardsley, Compelling Contract Performance in France, 1 Hastings Int'l Comp. L. Rev. 93 (1977) (France); Eugen Bucher, Law of Contracts, in Introduction to Swiss Law 107, 115 (Francois Dessemontet ed., 2004) (Switzerland).

${ }^{48}$ Lando and Rose report that enforcement of specific performance in France appears limited to the enforcement of construction contracts under threat of a mandated cover purchase or for the delivery of already completed goods. Lando \& Rose, supra note 4 , at 479 .

${ }^{49}$ Id. at 476.

${ }^{50}$ Id at 478.

${ }^{51} J a n$ Hellner, Specific Performance, in Swedish Contract Law 15 (Stockholm Institute for Scandinavian Law).

${ }^{52}$ Luca Ficetola, Comparing Remedies for Breach of Contract in Italian and English Law 10 (U. London School of Law, Working Paper), available at <http://papers.ssm.com/sol3/papers.cfm?abstract_id=199079l>.

${ }^{53}$ Lando \& Rose, supra note 4, at 475-77. The plaintiff can bring criminal suit against the defendant should it fail to perform, but, according to Lando and Rose, there has only been one such suit in recent times. From a study of all cases reported in the Danish Weekly Law Report between 1950-2000, they found only two cases where specific performance was demanded and none where it was granted. They conclude that specific performance in Denmark is dead in all but name. Id. at 474 .

${ }^{54}$ Patcison \& Herron, supra note 46 , at 475. 
In the United States and other common-law countries, the preference for damages over specific performance is not as clear-cut as may appear from formal judicial pronouncements. Although common-law systems ostensibly prefer damages, courts often award specific performance on the theory that the remedy at law is inadequate..$^{55}$ The stringency of the rule appears to be softening; ${ }^{56}$ for example, whereas in times past courts in sales litigation allowed specific performance only for transactions involving unique goods, more recently courts have dispensed with this requirement, allowing specific performance when damages are considered to be inadequate, even if the goods are not unique. ${ }^{57}$ The Uniform Commercial Code (UCC) also nudges judges toward a middle ground of granting specific performance. UCC $\S 2-716$ calls for specific performance in the case of unique goods as well as "in other proper circumstances." The section's first comment states that "this Article seeks to further a more liberal attitude than some courts have shown in connection with the specific performance of contracts of sale." ${ }^{58}$ The UCC also calls for specific performance when the "parties have agreed to that remedy"-thus endorsing the ability of parties to contract around the traditional rule. ${ }^{59}$

International agreements and standards also reflect a substantial degree of congruence with international standards. While the U.N. Convention for the International Sale of Goods (CISG), the Principles of European Contract Law (PECL), and the Draft Common Frame of Reference (DCFR) each specify that specific performance shall be an available remedy for breach, each likewise provides a hefty list of situations in which it shall not be granted. ${ }^{60}$ CISG explicitly states that judges are not required to grant specific performance if it is contrary to what the court would have ruled given its own

\footnotetext{
${ }^{55}$ Douglas Laycock, The Death of the Irreparable Injury Rule, 103 Harv. L. Rev. 687, 691 (1990) ("Courts have escaped the rule by defining adequacy in such a way that damages are never an adequate substitute for plaintiff's loss. Thus, our law embodies a preference for specific relief if plaintiff wants it."). See also Douglas Laycock, The Death of the Irreparable Injury Rule (1991); Caprice L. Roberts, The Restitution Revival and the Ghosts of Equity, 68 Wash. \& Lee L. Rev. 1027, 1034 (2011) ("In my opinion, the rule is not alive and well but, rather, rattles about like the undead.").

${ }^{56}$ See E. Allan Farnsworth, Contracts 746-47 (4th ed. 2004) ("The tendency is, however, to liberalize the granting of specific performance and injunction by enlarging the classes of cases in which damages are regarded as an inadequate remedy. The contemporary approach is to compare remedies to determine which is more effective in affording suitable protection to the injured party's legally recognized interest, which is usually that party's expectation interest. The concept of adequacy has thus tended to become relative, and the comparison more often leads to granting equitable relief than was historically the case.").
}

\footnotetext{
${ }^{57}$ See Mark P. Gergen, John M. Golden \& Henry E. Smith, The Supreme Court's Accidental Revolution? The Test for Permanent Injunctions, 112 Colum. L. Rev. 203, 225 (2012) ("In times long past, specific performance of a contract to sell goods was limited to unique goods. This rule has softened to allow specific performance in situations in which damages are an inadequate remedy for any reason, at least if other considerations do not cut against injunctive relief.") (footnote omitted).
}

${ }^{58}$ UCC $\$$ 2-716, comment. 1.

${ }^{59}$ UCC $\$ 2-716(1)$.

${ }^{60}$ De Vries, supra note 4. 
law. ${ }^{61}$ Meanwhile, PECL and DCFR have included the least common denominator of exceptions to specific performance: not for personal service contracts, not if it creates unreasonable burden or expense. ${ }^{62}$

Overall, comparative analysis suggests that successful legal systems can support substantial difference in contract remedies, but that the degree of convergence in remedial regimes is larger than would appear from an analysis of black-letter law alone.

\section{B. Experimental or Statistical Studies}

There is by now an impressive literature analyzing contracts from an experimental or statistical point of view. ${ }^{63}$ Only a few papers, however, address issues pertinent to contract remedies. Sloof et al. developed a game-theoretical model to test the efficiency of breach remedies. ${ }^{64}$ They allowed 80 volunteers to earn cash, an average of $\$ 21$, based on performance in a two-hour computer game. The game asked them to choose various levels of reliance investment for theoretical contracts, and to do so under various remedy defaults. Participants made more efficient investments when the default was specific performance as opposed to liquidated damages. The authors conclude that specific performance might

\footnotetext{
${ }^{61}$ Id. at 583-84 (quoting CISG art. 28: "If, in accordance with the provisions of this convention, one party is entitled to performance of any obligation by the other party, a court is not bound to enter a judgement for specific performance unless the court would do so under its own law in respect of similar contracts of sale not governed by this Convention.").
}

${ }^{62}$ Id. at $587-88$.

${ }^{68}$ In addition to our own work cited in note 7 supra, see, e.g., Oren Bar-Gill \& Ryan Bubb, Credit Card Pricing: The Card Act and Beyond, 97 Cornell L. Rev. 967 (2012); Christopher R. Drahozal \& Peter B. Rutledge, Arbitration Clauses in Credit Card Agreements: An Empirical Study, 9 J. Empirical Legal Stud. 536 (2012); Adam B. Badawi, Relational Governance and Contract Damages: Evidence from Franchising, 7 J. Empirical Legal Stud. 743 (2010); Erin O'Hara O'Connor, Kenneth J. Martin \& Randall S. Thomas, Customizing Employment Arbitration, 98 Iowa L. Rev. 133 (2012); Randall Thomas, Erin O'Hara \& Kenneth Martin, Arbitration Clauses in CEO Employment Contracts: An Empirical and Theoretical Analysis, 63 Vanderbilt L. Rev. 959 (2010); Florencia Marotta-Wurgler, Are "Pay Now, Terms Later" Contracts Worse for Buyers? Evidence from Software License Agreements, 38 J. Legal Stud. 309, 312-13 (2009); Florencia Marotta-Wurgler, Competition and the Quality of Standard Form Contracts: The Case of Software License Agreements, 5 J. Empirical Legal Stud. 447 (2008); Florencia Marotta-Wurgler, What's in a Standard Form Contract? An Empirical Analysis of Software License Agreements, 4 J. Empirical Legal Stud. 677 (2007); Stewart J. Schwab \& Randall S. Thomas, An Empirical Analysis of CEO Employment Contracts: What Do Top Executives Bargain For? 63 Wash. \& Lee L. Rev. 231 (2006); Omri Ben-Shahar \& James J. White, Boilerplate and Economic Power in Auto Manufacturing Contracts, in "Boilerplate": Foundations of Market Contracts Symposium, 104 Mich. L. Rev. 953 (2006); Steven N. Kaplan \& Per Stromberg, Financial Contracting Theory Meets the Real World: An Empirical Analysis of Venture Capital Contracts, 70 Rev. Econ. Stud. 281 (2003); Mary M. Shirley \& Lixin Colin Xu, Information, Incentives, and Commitment: An Empirical Analysis of Contracts Between Government and State Enterprises, 14 J. L. Econ. \& Org. 358 (1998). For general discussions of the potential contributions of empirical analysis to contract law scholarship, see, e.g., George S. Geis, Automating Contract Law, 83 NYU L. Rev. 450 (2008); Ian Ayres, Valuing Modern Contract Scholarship, 12 Yale L.J. 881, 900 (2003); Russell Korobkin, Empirical Scholarship in Contract Law: Possibilities and Pitfalls, 2002 U. Ill. L. Rev. 1033; David V. Snyder, Go Out and Look: The Challenge and Promise of Empirical Scholarship in Contract Law, 80 Tulane L. Rev. 1009, 1009-10 (2006); Eric A. Posner, Economic Analysis of Contract Law After Three Decades: Success or Failure? 112 Yale L.J. 829 (2003).

${ }^{64}$ Randolph Sloof, Hessel Oosterbeek, Arno Riedl \& Joep Sonnemans, Breach Remedies, Reliance and Renegotiation, 26 Int'l Rev. L. \& Econ. 263 (2006). 
perform better than judicially awarded or liquidated damages as a device for encouraging efficient reliance expenditures. ${ }^{65}$

Wilkinson-Ryan and Baron surveyed a representative sample of Americans, presenting them with a scenario involving a breached home renovation contract and asking them to set damages and express a preference for either damages or specific performance. ${ }^{66}$ They found that the respondents expressed surprisingly strong support for specific performance as a remedy: "Not only did 75 percent of participants believe that the promisor ought to perform rather than pay damages, 66.7 percent of subjects believed that the court should enforce specific performance. Subjects thought that even supracompensatory damages were a morally inferior remedy to performance ..."67

In a subsequent paper, Wilkinson-Ryan and Hoffman theorize that the marked preference for injunctive relief is evidence of dignitary harm associated with contract breach. ${ }^{68}$ Wilkinson-Ryan and Hoffman found that respondents demanded greater damages when breaches of contract were efficient and opportunistic, as when the promisor breaches because she received a better offer from a third party, in contrast with an unintentional breach caused by cost overruns.

Using web-based questionnaires, Wilkinson-Ryan investigated how liquidated damages provisions in contracts affected parties' decisions about whether to breach. ${ }^{69}$ Subjects were more willing to exploit efficient-breach opportunities when the contract in question includes a liquidated damages clause. Wilkinson-Ryan concludes that "when interpersonal obligations are informal or underspecified, people act in accordance with shared community norms, like the moral norm of keeping promises. However, when sanctions for uncooperative behavior are specified or otherwise formalized between the parties, behavior becomes more strategic and more self-interested."70

Despite these contributions, the empirical literature on specific performance versus contract damages remains quite undeveloped. Our investigation revealed no papers analyzing a data set of actual contracts instead of employing experiments or survey methodology. The paucity of empirical investigation in this area lends a certain degree of abstractness to the analytical discussions, which may depend fundamentally on untested

\footnotetext{
${ }^{65}$ Id. at 291. ("Our results ... suggest that a simple specific performance clause may perform better than a carefully determined liquidated damages breach remedy. Put differently, to protect reliance expenditures it may be preferable to use a 'property rule' rather than a 'liability rule'.").
}

${ }^{66}$ Tess Wilkinson-Ryan \& Jonathan Baron, Moral Judgment and Moral Heuristics in Breach of Contract, 6 J. Empirical Legal Stud. 405 (2009).

${ }^{67}$ Id. at 420.

${ }^{68}$ Tess Wilkinson-Ryan \& David A. Hoffman, Breach is for Suckers, 63 Vanderbilt L. Rev. 1003 (2010).

${ }^{69}$ Tess Wilkinson-Ryan, Do Liquidated Damages Encourage Breach? A Psychological Experiment, 108 Mich. L. Rev. $633(2010)$.

${ }^{70}$ Id. at 633 . 
assumptions about how people actually behave in real-world contractual settings. ${ }^{71}$ The shortage of empirical evidence has even led some to bemoan the lack of studies on the topic; as one commentator puts it, "more empirical research would be helpful."72

\section{DATA AND Hypotheses}

\section{A. The Data}

The data consist of 12 types of material contracts contained as exhibits to Form 8-K "current report" filings with the SEC in $2002 .{ }^{73}$ Form 8 -K must be filed by SEC-reporting firms to disclose certain material corporate events or changes that have not previously been reported by the company. ${ }^{74}$ We searched all Form 8-K filings and coded information about any contract that fit into one of Table 1's categories. We eliminated contracts that did not fit into one of the 12 contract types described below and 67 contracts for which suitable fee clause information was not available. The resulting sample consisted of 2,347 contracts.

We coded the contracts for a variety of contract terms, including terms related to the settlement of disputes that might arise under the contract, as well as information on the nature and location of the contracting parties. We also coded the type of contract, as shown in Table 1. For 11 contract categories, six months' worth of contracts, covering the period

\section{Table 1: Types of Contracts Studied (Number of} Contracts in Parentheses)

\begin{tabular}{ll}
\hline Asset sale/purchase (299) & Pooling and servicing (169) \\
Bond indentures (154) & Securities purchase (442) \\
Credit commitments (215) & Security agreements (35) \\
Employment (109) & Settlements (71) \\
Licensing (46) & Trust agreements (45) \\
Mergers (410) & Underwriting (352) \\
\hline
\end{tabular}

Source: SEC EDGAR database, LEXIS EDGAR PLUS database, Jan. 2002 to June 30, 2002 for all contract types other than mergers and Jan. 2002 to July 31, 2002 for merger contracts.

\footnotetext{
${ }^{71}$ See, e.g., Richard Craswell, Promises and Prices, in Symposium-Contract as Promise at 30: The Future of Contract Theory, 45 Suffolk U. L. Rev. 735, 772, 773 (2012) (noting cases where theoretical arguments depend on empirical assumptions); Katz, supra note 19, at 785 (arguments for the damages remedy depend on "empirical presuppositions").

${ }^{72}$ George Triantis, Promissory Autonomy, Imperfect Courts, and the Immorality of the Expectation Damages Default, in Symposium-Contract as Promise at 30: The Future of Contract Theory, 45 Suffolk U. L. Rev. 827, 840 n.39 (2012); see also Klass, supra note 43, at 147 ("One wants some empirical evidence for Markovits and Schwartz's empirical interpretive claim.").

${ }^{79}$ See Table 1.

${ }^{74}$ For the current rules on filing a Form 8-K, see Securities and Exchange Commission, Form 8-K, <http://sec.gov/ about/forms/form8-k.pdf> (specifying certain material events that an issuer must report by filing a Form 8-K with the Securities and Exchange Commission).
} 
January 1 to June 30, 2002, were studied. For merger contracts, the study covered a seven-month period from January 1 to July 31, 2002. The slightly expanded period for merger contracts draws on our earlier work on choice of law and choice of forum in merger contracts. ${ }^{75}$ Most of the contract types are self-explanatory. "Pooling and servicing" contracts are used in mortgage pass-through and other asset-backed securities arrangements; they represent agreements under which an owner transfers receivables to a trustee, which holds title to and collects the income from the assets and passes the funds through to investors. ${ }^{76}$ Trust agreements establish these trusts and define certain of their powers and responsibilities. ${ }^{77}$

Securities purchase agreements were the most frequent contract type, accounting for 18.8 percent of the total. Credit-related contracts-bond indentures, credit commitments, pooling and servicing agreements, and security agreements-accounted for another 24 percent. Merger contracts were about 17 percent of the sample but note that they had one extra month of coverage in the data. Together, the contract types offer a reasonably rich variety of relations. Several contract types, including the credit-related contracts, obviously involve substantial financial institutions. Others, asset sale/purchase and merger contracts, typically involve corporate restructurings. Settlements involved resolution of disputes. Employment contracts offer insights into dispute resolution contract terms in agreements between key employees and large corporate employers.

The key outcome variable in this study is the contracts' treatment of remedies, with particular focus on the remedy commonly referred to as specific performance. To determine whether a contract included specific performance as a remedy, we used terms associated with departures from the default damages rule. We searched the retrieved SEC documents for the following terms: "specific!, injunc!, irre! (to capture Irreparable and Irrevocable), adequate, equit!, remedies, relief." The "!" symbol in some of the search terms is the commonly used symbol to include any combination of characters that follow the root term. For example, "injunc!" would include documents that contain the words "injunction" or "injunctive." Documents that satisfied the search term were then read to ascertain whether they in fact addressed specific performance.

Search terms, however broad, may not capture the full diversity of contractual clauses relating to specific performance. For example, underwriting agreements often involve more than one underwriter of issued securities. A common term in underwriting agree-

\footnotetext{
${ }^{75}$ See Eisenberg \& Miller, Ex Ante Choices of Law and Forum, supra note 8, at 1981, 1983-84.

${ }^{76}$ See, e.g., Circuit City Credit Card Master Trust, Form 8-K, Exh. 4.2: Amended and Restated Master Pooling Service Agreement, at 41-187, Dated as of Dec. 31, 2001, filed Jan. 31, 2002, Doc. No. 02523859. See generally Thomas E. Plank, The Security of Securitization and the Future of Security, 25 Cardozo L. Rev. 1655, 1662 (2004) (describing this type of agreement as a particular asset-backed security-a pure pass-through certificate-in which "the owner of the receivables transfers them to a trustee pursuant to a trust agreement in exchange for certificates that represent a 100 percent beneficial ownership interest in the receivables").
}

${ }^{77}$ See, e.g., First Consumers National Bank, Form 8-K, Exh. 4.3, Trust Agreement Between First Consumers Credit Corporation, as Seller, and Bankers Trust Company, as Owner Trustee, at 213-45, dated as of Mar. 1, 2001, and amended and restated as of Dec. 31, 2001, filed Jan. 31, 2002, Doc. No. 02524022 See Planck, supra note 75, at $1662-67$. 
ments requires nondefaulting underwriters to purchase securities that should have been purchased by a defaulting underwriter. ${ }^{78}$ This does not require specific performance by a defaulting underwriter but can achieve similar effect from the issuer's perspective if the nondefaulting underwriters must purchase the defaulted securities. To the extent that the securities issuer achieves the functional equivalent of specific performance, albeit not from the defaulting contractual counterparty, the nondefaulting underwriter provision suggests a demand for specific performance in underwriting contracts. ${ }^{79}$ Such provisions continue to be used frequently as of this writing. ${ }^{80}$

\section{B. Hypotheses}

We separate our hypotheses into two groups. The first group of hypotheses is based on considerations that are external to the particular contracts in our sample. These hypotheses relate to ex ante views of the benefits of specific performance, the nature of the relationships between the parties to the extent derivable from the contracts we observe, the likely specific appeal of specific performance in some types of transactions, such as mergers and loan transactions, and the parties' connection to a civil-law or common-law background. Each of these factors might be expected to be associated with the rate of providing for specific performance in any relevant set of contracts. These hypotheses, however, are not based on the parties' behavior as evidenced by other terms in the sample contracts.

\footnotetext{
${ }^{78}$ See, e.g., Northwestern Corporation, Form 8-K, Exh.1.1: 8.10\% Trust Preferred Securities Underwriting Agreement $\S 10$, at 24, Jan. 24, 2002, filed Jan. 31, 2002, SEC File No.: 001-10499, Accession No.: 0000912057-02-003623; Bank of America Corporation, Form 8-K, Exh.1.1: BAC Capital Trust II 7\% Capital Securities (Liquidation Amount of \$25 per Capital Security) Underwriting Agreement \$ 8, at 23, Jan. 24, 2002, filed Jan. 31, 2002, SEC File No.: 001-06523, Accession No: $0000895527-02-000010$. Both underwriting agreements contain the following or similar language:

If one or more of the Underwriters shall fail at Closing Time or the relevant Date of Delivery, as the case may be, to purchase the Preferred Securities which it or they are obligated to purchase under this Agreement (the "Defaulted Securities"), the Representatives shall have the right, within 24 hours thereafter, to make arrangements for one or more of the non-defaulting Underwriters, or any other underwriters, to purchase all, but not less than all, of the Defaulted Securities. ...
}

Variations on this language appears in many underwriting agreements. Gulf Power Company, Form 8-K, Exh.1.1: $\$ 45,000,000$ Series E 6.00\% Senior Notes Underwriting Agreement $\$ 10$, Jan. 18, 2002, filed Jan. 30, 2002, SEC File No.: 000-02429, Accession No.: 0000044545-02-000002 (obligating nondefaulting underwriters to purchase defaulted securities); Ford Motor Company, Form 8-K, Exh.1.1: Ford Motor Company Capital Trust II, _\% Cumulative Convertible Trust Preferred Securities (Liquidation Preference $\$ 50$ per Preferred Security) [Form of Underwriting Agreement] $\$ 10$, at 22, _, 2002, filed Jan. 30, 2002, SEC File No.: 001-03950, Accession No.: 0000950124-02-000164 (obligating nondefaulting underwriters to purchase defaulted securities).

\footnotetext{
${ }^{79}$ Underwriters may be more willing to agree to specific performance by nondefaulting underwriters when multiple underwriters share this risk. When only one additional underwriter is present, there may be less willingness to bear this risk. Nelnet Student Loan Funding, LLC, Form 8-K, Exh.1.1: Nelnet Student Loan Trust 2002-1, \$1,036,270,000 Student Loan Asset-Backed Notes Underwriting Agreement $\$ 11$, at 20, May 9, 2002, filed June 3, 2002, SEC File No.: 333-82280, Accession No.: 0000870156-02-000034 (remaining underwriter has the right, but not the obligation, to purchase defaulted notes).
}

${ }^{80}$ E.g., NYSE Euronext, Form 8-K, Exh.1.1: NYSE Euronext $\$ 850,000,0002.000 \%$ Notes Due 2017 Underwriting Agreement $\$ 10$, at 22, Oct. 1, 2012, filed Oct. 5, 2012, SEC File No.: 001-33392 Accession No.: 0000950103-12-005290 (obligating nondefaulting underwriters to purchase defaulted securities). 
The second group of hypotheses builds on our prior research using the same contracts studied here. These hypotheses exploit the knowledge we have gained by substantial prior study of the sample contracts. We have published results relating to these contracts' use or rejection of several default contract rules. Our prior findings show (1) overwhelming acceptance of the default rule of access to a judicial forum, in contrast to arbitration, as the preferred forum for adjudication; (2) substantial acceptance of the default rule of availability of jury trial in the judicial forum; (3) substantial rejection of the default American rule on attorney fees, under which each party pays its own litigation costs; and (4) approximately even division between specifying a litigation forum compared to accepting the risk of default jurisdiction and venue rules determining the litigation forum.

These prior findings are relevant to studying use of specific performance clauses because they constitute information about the parties' willingness to invest the time and effort to specify nondefault terms in these contracts. Parties who invested the time and effort to specify, for example, arbitration or waiver of jury trial, are more likely to invest the time and effort to address the topic of specific performance rather than passively accept the default rule disfavoring specific performance.

\section{Hypotheses Based on External Considerations}

We explore five hypotheses based on general considerations relating to specific performance, the parties' relationships, the type of contract, and the parties' background legal systems.

\section{The data will reveal substantial levels of opting out of the traditional damages rule.}

This hypothesis is based on the literature, cited above, which demonstrates that, at a minimum, no consensus exists as to the respective advantages and disadvantages of damages and specific performance as remedies for contract breach. If contracting parties credit the argument that specific performance generates more efficient outcomes, they will tend to opt out of the damages rule as a matter of self-interest. Contracting parties might also opt out of the damages remedy to the extent they accept the moral argument in favor of specific performance, provided that their decisions about contract terms are at least partially determined by considerations of morality in addition to self-interest.

\section{Parties will opt out of the damages mule more frequently in the case of relational contracts.}

The hypothesis with respect to relational contracts is based on several considerations. First, such contracts are likely to be ones where the parties are averse to breach. Theory predicts that specific performance remedies reduce the probability of breach relative to damages remedies. ${ }^{81}$ Thus we predict that waivers of the irreparable harm condition will be observed

\footnotetext{
${ }^{81}$ See Aaron Edlin, Cadillac Contracts and Up-Front Payments: Efficient Investment Under Expectation Damages, 12 J. L. Econ. \& Org. 98 (1996); Aaron Edlin \& Stephen Reichelstein, Holdups, Standard Breach Remedies, and Optimal Investment, 86 Am. Econ. Rev. 478 (1996); Benjamin E. Hermalin \& Michael L. Katz, Moral Hazard and Verifiability:
} 
more frequently in relational contracts. Second, relational contracts are likely to induce greater expenditures on reliance, some of which would not be compensable under a damages remedy. ${ }^{82}$ To avoid loss of reliance expenditures, the contracting parties are likely to waive the irreparable harm condition. Third, parties to relational contracts may opt for specific performance in order not to introduce uncertainty into contract negotiations-a point developed in work by Alan Schwartz, ${ }^{83}$ who reasons that specific performance reduces uncertainty about the remedy a court would award for breach and, therefore, also reduces opportunities for opportunistic behavior. ${ }^{84}$

\section{Parties will opt out of the damages rule more frequently in the case of merger contracts.}

Merger contracts involve acquisitions of firms operating as going concerns. Since these are difficult to value, we predict that the parties will prefer specific performance to damages as a remedy for breach, at least when the contract does not contain explicit termination fees. ${ }^{85}$ For example, one merger agreement's specific performance clause states:

The parties agree that irreparable damage would occur, and that the parties would not have any adequate remedy at law, in the event that any of the provisions of this Agreement were not performed in accordance with their specific terms or were otherwise breached. ${ }^{86}$

However, the omission of a specific performance term in a merger contract does not necessarily imply that the parties disfavored this remedy. Contracts drafted in 2001 probably reflected special awareness of the fact that specific performance could often be awarded in merger contracts due to a much-discussed decision by the Delaware Court of Chancery the previous year, ${ }^{87}$ which held under New York law that a breaching party was required to go through with a merger agreement-in other words, ordering specific performance of the

The Effects of Renegotiation in Agency, 59 Econometrica 1735 (1991); Alexander Triantis \& George Triantis, Timing Problems in Contract Breach Decisions, 541 J. L. \& Econ. 163 (1999).

${ }^{82}$ E.g., Ofer Grosskopf \& Barak Medina, Regulating Contractual Formation: Precontractual Reliance, Sunk Costs, and Market Structure, 39 Conn. L. Rev. 1977, 1979 (2007) (precontractual reliance expenditures are relationship specific and not wholly recoverable).

${ }^{83}$ See Alan Schwartz, Relational Contracts in the Courts: An Analysis of Incomplete Agreements and Judicial Strategies, 21 J. Legal Stud. 271 (1992); Alan Schwartz, Incomplete Contracts, in Peter Newman, ed., The New Palgrave Dictionary of Economics and the Law (London: Macmillan Reference 1998).

${ }^{84}$ See Schwartz, supra note 35.

${ }^{85}$ See Afra Afsharipour, Transforming the Allocation of Deal Risk Through Reverse Termination Fees, 63 Vanderbilt L. Rev. 1161, 1168 (2010) (finding that the "vast majority" of private equity transactions included a right for the seller to seek the remedy of specific performance).

${ }^{86}$ Agreement and Plan of Merger, Dated as of May 7, 2002, By and Among Olin Corporation, Plumber Acquisition Corp., and Chase Industries $\$ 8.09$.

${ }^{87}$ IBP, Inc. v Tyson Foods, Inc., 789 A.2d 14 (Del. Ch. 2001). 
merger contract. In ordering the remedy, the court observed that damages were difficult to quantify, that the merger continued to make strategic sense, and that the combined firm could be effectively managed if specific performance were granted-features that are likely to be present in many merger deals. Nevertheless, although the parties may be able to obtain specific performance ex post even in the absence of an opt-out clause, the presence of such a class cannot hurt and may help cement the argument in favor of the specific performance remedy.

4. Parties will opt out of the damages rule more frequently in the case of contracts involving counterparties from civil-law countries, but not in the case of counterparties from common-law countries.

This hypothesis rests on the comparative research discussed above, which reveals that civil-law countries tend to administer regimes of contract remedies that formally endorse specific performance as a remedy. However, since this research reveals that the contrast between civil- and common-law rules is often not clear-cut, it may be that the issue of contract remedies will not be salient in many cases where the counterparties are from jurisdictions with formally conflicting remedial rules.

\section{Parties will opt out of the damages rule less frequently in the case of financial contracts.}

This hypothesis is based on financial contracts typically requiring the payment of money. In such cases, damages will usually be an adequate substitute for performance; or, alternatively, since the measure of specific performance would be the same as the measure of damages liability, the parties have no particular reason to opt out of the damages rule. However, even financial contracts may provide for specific performance for obligations other than the obligation to pay interest and principal. Covenants to perform can cover a range of behavior, breach of which may be difficult to value, thus creating an incentive for specific performance provisions. ${ }^{88}$

\section{Hypotheses Related to Treatment of Other Default Rules in These Contracts}

Additional hypotheses we explore are related and are in a sense a single hypothesis that we can test using different contract clauses. The contracts' treatment of four other default rules (arbitration, jury trial, attorney fees, litigation forum) provides information about the parties' willingness, in these contracts, to transcend default rules. We expect that departing from any default rule is associated with departing from other default rules. This is because

\footnotetext{
${ }^{88} \mathrm{~A}$ discussion of default provisions in indentures states:
}

Where the obligor's default arises from a failure to abide by an obligation (other than its obligation to pay interest and principal), the indenture trustee and bondholders may seek an injunction or specific performance. In certain cases, the courts may even permit such a suit before the default matures into an event of default under the trust indenture. See Guardian Trust Co. v. Whitecliff Portland Cement \& Chalk Co., 109 F. 523 (5th Cir. 1901).556 PLI/Comm 23: Practising Law Institute, Commercial Law and Practice Course Handbook Series, PLI Order No. A44318. Steven R. Gross, Richard F. Hahn, Azizah Y. al-Hibri \& George E.B. Maguire, Restructuring Public Debt Outside of Chapter 11, in Investing in the Troubled Company 1990, 23, 48 (Oct. 1-2, 1990). 
parties who contracted around at least one default rule had to expend effort to do so and we expect that willingness to expend that effort is not limited to a single default rule. Parties who modified any default rule thus might be expected to modify other default rules. In the context of specific performance clauses, we therefore forecast that contracts that depart from other default rules are more likely to depart from the default damages rule. This translates into four additional testable hypotheses.

6. Parties will opt out of the damages rule more frequently in the case of contracts containing mandatory arbitration clauses.

This hypothesis, motivated by the expected associations among waiving default rules, may have to be tempered by a countervailing consideration specific to the default rule waived via an arbitration clause (availability of a judicial forum). Where a contract contains a mandatory arbitration clause, the dispute will very likely be resolved by an arbitrator. Although arbitrators have the formal authority to award specific performance as well as damages, to the extent that the expectation is that the award will consist of money payments, ${ }^{89}$ the parties may anticipate and prefer that the remedy, if any, take the form of damages rather than specific performance. So the willingness to question the default rule of access to a judicial forum, while forecasting willingness to question the default damages rule, may be outweighed by an expectation of damages in arbitration.

7. Parties will opt out of the damages rule more frequently in the case of contracts containing jury trial waivers.

In the case of the jury trial default rule, an additional consideration strengthens the likely effect of willingness to depart from one rule being evidence of willingness to depart from another rule. The presence of a jury trial waiver in a contract indicates that the parties prefer courts to civil juries as factfinders in disputes over their contracts. Because specific performance is an equitable remedy, it will be ordered by a court, whereas damages, the classic legal remedy, will often be determined by a jury. If the parties prefer courts to juries, they may opt out of the damages rule in order to obtain further assurance that their preferred decisionmaker will be selected to adjudicate their disputes.

8. Parties will opt out of the damages rule more frequently in the case of contracts that depart from the default American Rule governing attomey fees.

Willingness to depart from the default fee rule is again evidence that the parties, or their attorneys, thought through the issues relating to default rules governing dispute resolution. Parties willing to invest in negotiating a nondefault fee rule may also be more likely to negotiate out of the default damages rule.

\footnotetext{
${ }^{89}$ See Daniel Markovits, Arbitration's Arbitrage: Social Solidarity at the Nexus of Adjudication and Contract, in Winter 2010 Symposium Rising Stars: A New Generation of Scholars Looks at Civil Justice, Fifteenth Annual Clifford Symposium on Tort Law and Social Policy, 59 DePaul L. Rev. 431, 479 (2010).
} 


\section{Parties will opt out of the damages rule more frequently in contracts containing forum selection or choice of law clauses.}

Unlike arbitration and jury trial waivers, the presence of a forum selection clause is not easily associated with some normative insight about the parties' preference for the default damages rule. In the case of forum selection clauses, the evidence of willingness to depart from default rules is likely the dominant effect. That is, the presence of a forum selection clause in a contract indicates that the parties, or their attorneys, have evaluated some of the issues concerning how the dispute will be litigated. In such a case, the parties may also be more likely to make a deliberate decision to opt out of the damages rule rather than allowing the default rule to govern. Although similar reasoning applies to the relation between contracts specifying a choice of law clause and the expected presence of a specific performance clause, the inference of more careful thought with respect to having specified a choice of law clause cannot easily be tested. This is because virtually all the contracts in our sample specify a choice of law whereas only 39 percent of contracts specify a choice of forum. ${ }^{90}$

10. Parties will opt out of the damages rule less frequently in the case of contracts selecting a New York or Delaware forum.

Our prior study of choice of forum clauses in these contracts showed that sophisticated contracting parties tended to prefer New York and Delaware courts as the source of forum governing large commercial contracts. ${ }^{91}$ If this preference reflects confidence in the quality and reliability of the New York and Delaware court systems, the parties might be willing to trust that the determination of damages will be reasonably accurate in these courts. On the other hand, if New York or Delaware was not chosen as a litigation forum, the parties may be less willing to trust that the courts from other states will accurately assess damages. In such cases, the parties may prefer to select specific performance as a remedy, since specifying the remedy may give less scope to the discretion of the courts.

The association between departing from more than one default rule is, of course, not limited to associations between the treatment of other default rules and the treatment of specific performance. Since this study, together with our prior studies, ${ }^{92}$ reports individual default rule information for five default rules (including specific performance), we can analyze the associations of departure rates across all pairs of default rules. We first present results relating to specific performance and then include analysis of the associations among other departure rules in the discussion of results in Section VI.

\footnotetext{
${ }^{90}$ Eisenberg \& Miller, The Flight to New York, supra note 7 , shows that such a high proportion of contracts specified choice of law that the number not specifying choice of law was not mentioned, id. at 1490 (tbl. 2), whereas choice of forum was specified in only 39 percent of contracts. Id. at 1504 (tbl. 11).

${ }^{91}$ Id. at 1504 (showing that only Delaware and New York accounted for at least 10 percent of the contracts specifying a litigation forum). Forum selection clauses are ordinarily enforced in U.S. courts. E.g., Restatement (Second) of Conflict of Laws $\$ 80$ (1989) ("The parties' agreement as to the place of the action will be given effect unless it is unfair or unreasonable."); Eisenberg \& Miller, The Flight to New York, supra, at 1503 n.79.
}

\footnotetext{
${ }^{92}$ See sources cited at note 7 supra.
} 


\section{RESULtS}

Our specific performance results first show the relation between each explanatory variable of interest and whether a contract contained a specific performance clause. We then report regression models and classification and regression tree (CART) results that account for multiple explanatory variables.

\section{A. Bivariate Results}

Our first hypothesis is that there will be substantial levels of opting out of the traditional damages rule. What counts as substantial is a subjective question and we therefore approach this hypothesis in two ways. Table 2's third row reports the number and percent of contracts that included provisions allowing for specific performance. The express allowance of specific performance in 31.5 percent of the contracts, though not a majority of contracts, is a substantial rate of authorizing specific performance. The substantial rate confirms the first hypothesis, namely, that the contracts under review frequently opt out of the traditional damages rule. ${ }^{93}$

Table 2: Rate of Accepting Default Rule, by Kind of Dispute Resolution Clause

\begin{tabular}{|c|c|c|c|c|c|}
\hline \multirow[b]{2}{*}{ Dispute Resolution Clause } & \multicolumn{3}{|c|}{ Number of Contracts } & \multicolumn{2}{|c|}{ Percent of Contracts } \\
\hline & $\begin{array}{c}\text { Accept } \\
\text { Default } \\
\text { Rule }\end{array}$ & $\begin{array}{l}\text { Opt Out } \\
\text { of Default } \\
\text { Rule }\end{array}$ & Total & $\begin{array}{c}\text { Accept } \\
\text { Default } \\
\text { Rule }\end{array}$ & $\begin{array}{c}\text { Opt Out } \\
\text { of Default } \\
\text { Rule }\end{array}$ \\
\hline Arbitration (default $=$ no arbitration) & 2,554 & 304 & 2,858 & $89.4 \%$ & $10.6 \%$ \\
\hline Jury trial (default $=$ no waiver $)$ & 2,256 & 560 & 2,816 & $80.1 \%$ & $19.9 \%$ \\
\hline Specific performance $($ default $=$ not available $)$ & 1,604 & 737 & 2,341 & $68.5 \%$ & $31.5 \%$ \\
\hline Attorney fees (default $=$ American Rule $)$ & 870 & 1,477 & 2,347 & $37.1 \%$ & $62.9 \%$ \\
\hline
\end{tabular}

Noтe: The major differences among the numbers of contracts in the total column is due to excluding the contract category "Other" from this study.

Sources: Eisenberg and Miller, The Flight from Arbitration, supra note 7, at 351 (tbl. 2); Eisenberg \& Miller, The English vs. the American Rule, supra note 7, at 352 (tbl. 2); Eisenberg \& Miller, Do Juries Add Value? supra note 7, at 553 (tbl. 2); SEC EDGAR database, LEXIS EDGAR PLUS database, Jan. 2002 to June 30, 2002 for all contract types other than mergers and Jan. 2002 to July 31, 2002 for merger contracts.

\footnotetext{
${ }^{93}$ The contracts we review in this article are far from the only ones to contain clauses opting out of the traditional rule. For example, confidentiality agreements in oil and gas transactions frequently contain such language. See Margaret L. Meister, Confidentiality Agreements and Due Diligence, in Rocky Mountain Mineral Law Foundation, Special Institute: Due Diligence in Mining and Oil \& Gas Transactions, 2010 Rocky Mountain Mineral Law Foundation Institute Paper No. 6 (2010) (setting forth model confidentiality agreement containing the provision that "Recipient agrees that if this Agreement is breached, or if a breach hereof is threatened, the remedy at law may be inadequate, and therefore, without limiting any other remedy available at law or in equity, an injunction, restraining order, specific performance, and other forms of equitable relief or money damages or any combination thereof shall be available to Provider"). Opt-out clauses are also apparently ubiquitous in private equity deals. See Afra Afsharipour, Transforming the Allocation of Deal Risk Through Reverse Termination Fees, 63 Vanderbilt L. Rev. 1161,1168 (2010).
} 
Table 3: Rate of Specific Performance Clauses, by Type of Contract

\begin{tabular}{|c|c|c|c|c|c|}
\hline \multirow[b]{2}{*}{ Contract Type } & \multicolumn{3}{|c|}{ Include SP: Number } & \multicolumn{2}{|c|}{ Include SP: Percent } \\
\hline & No & Yes & Total & No & Yes \\
\hline Asset sale purchase & 163 & 134 & 297 & 54.9 & 45.1 \\
\hline Bond indentures & 85 & 68 & 153 & 55.6 & 44.4 \\
\hline Credit commitments & 187 & 28 & 215 & 87.0 & 13.0 \\
\hline Employment contracts & 46 & 63 & 109 & 42.2 & 57.8 \\
\hline Licensing & 30 & 15 & 45 & 66.7 & 33.3 \\
\hline Mergers & 191 & 219 & 410 & 46.6 & 53.4 \\
\hline Pooling \& servicing & 152 & 16 & 168 & 90.5 & 9.5 \\
\hline Securities purchase & 283 & 158 & 441 & 64.2 & 35.8 \\
\hline Security agreements & 22 & 13 & 35 & 62.9 & 37.1 \\
\hline Settlements & 53 & 18 & 71 & 74.6 & 25.4 \\
\hline Trust agreements & 42 & 3 & 45 & 93.3 & 6.7 \\
\hline Underwriting & 350 & 2 & 352 & 99.4 & 0.6 \\
\hline Total & 1,604 & 737 & 2,341 & 68.5 & 31.5 \\
\hline
\end{tabular}

$\mathrm{SP}=$ specific performance.

SOURCE: SEC EDGAR database, LEXIS EDGAR PLUS database, Jan. 2002 to June 30,2002 for all contract types other than mergers and Jan. 2002 to July 31, 2002 for merger contracts.

Table 2 also offers a basis for comparing specific performance clauses to other dispute resolution clauses we have studied. In accordance with black-letter law, we regard the default specific performance rule to be that specific performance is not available. One can compare the 31.5 percent rate of rejecting that default rule with the rates at which contracting parties reject other contractual default rules. As Table 2 shows, the parties contract out of two other core dispute resolution features, no access to arbitration and access to jury trial, at much lower rates, 10.6 percent and 19.9 percent, respectively. But parties contract out of the default American Rule on attorney fees at a much higher rate than they contract out of the default damages rule. All differences in rates between the specific performance dispute resolution clause rate and the other three rates are highly statistically significant, with $p<0.001$.

Table 3 reports the rate at which different contract types included specific performance as a remedy. The inclusion rate varied substantially, with low rates of 0.6 percent and 6.7 percent in underwriting contracts ${ }^{94}$ and pooling and servicing agreements, respectively, to high rates of 57.8 percent and 53.4 percent in employment contracts and merger agreements, respectively. The high rate of specific performance in merger agreements supports our hypothesis that parties will opt out of the default damages rule more fre-

\footnotetext{
${ }^{94}$ One of the underwriting contracts that does mention specific performance provides for it by the issuer of securities for the benefit of the purchasers. Exchange and Registration Rights Agreement 9(b).E. The typical underwriting agreement makes no mention of specific performance. E.g., Underwriting Agreement Among Asset Backed Funding Corporation, Bank of America Securities LLC, Countrywide Securities Corporation, Well Fargo Brokerage Services, LLC (filed 4/9/2002).
} 
Table 4: Rate of Specific Performance Clauses, by Relational Contract Status

\begin{tabular}{lrrrrrr}
\hline & \multicolumn{2}{c}{ Include SP: Number } & & \multicolumn{2}{c}{ Include SP: Percent } \\
\cline { 2 - 4 } Contract & \multicolumn{1}{c}{ No } & Yes & Total & & No & Yes \\
\hline Nonrelational & 1,125 & 599 & 1,724 & 65.3 & 34.7 \\
Relational & 437 & 135 & 572 & 76.4 & 23.6 \\
Total & 1,562 & 734 & 2,296 & 68.0 & 32.0 \\
\hline
\end{tabular}

$\mathrm{SP}=$ specific performance.

SOURCE: SEC EDGAR database, LEXIS EDGAR PLUS database, Jan. 2002 to June 30,2002 for all contract types other than mergers and Jan. 2002 to July 31,2002 for merger contracts.

quently in such cases. The 53.4 percent rate is statistically significantly higher than the rate in nonmerger contracts $(p<0.001)$, does not significantly differ from the higher rate in employment contracts $(p=0.450)$, and does significantly differ from the next highest rate of 45.1 percent in asset sale or purchase contracts $(p=0.033)$. The table's last row shows the aggregate rate of specific performance clause use to be 31.5 percent, but this increases to 46.4 percent if one regards underwriting contracts as providing for specific performance, as discussed above. ${ }^{95}$

Table 4 reports the association between specific performance clauses and relational contract status. Coding contracts' relational status can be imprecise. A settlement, for example, may terminate a short-term or long-term relation, or it may promote a continued relation. We coded for relational status based on contract categories, with the following contract categories coded as more likely to be relational: credit commitments, employment, licensing, pooling and service agreements, and security agreements; and the following categories coded as less likely to be relational: asset sale or purchase, bond indentures, mergers, securities purchase agreements, settlements, and underwritings. We omitted trust agreements from the sample for purposes of the analysis of relational contracts because the relational status for these contracts is insufficiently clear.

Table 4 suggests a modest preference for specific performance in nonrelational contracts. The difference is highly statistically significant $(p<0.001)$, and contradicts our hypothesis that parties will opt out of the default damages rule more frequently in relational contracts.

We hypothesized that parties would opt out of the default damages rule more frequently in contracts involving counterparties from civil-law countries, but not in the case of counterparties from common-law countries other than the United States. The data do not support this hypothesis. Table 5 shows that 34.2 percent of contracts with a civil-law country counterparty provided for specific performance. This is a higher rate, but not a statistically significantly higher rate, than the 30.8 percent rate of specific performance in contracts with only U.S. parties. It is lower than the 39.1 percent rate of specific perfor-

\footnotetext{
${ }^{95}$ See text accompanying notes $78-80$ supra.
} 
Table 5: Rate of Specific Performance Clauses, by Legal System of Parties

\begin{tabular}{lcccccc}
\hline & \multicolumn{3}{c}{ Include SP: Number } & & \multicolumn{2}{c}{ Include SP: Percent } \\
Legal System & No & Yes & Total & & \multirow{2}{*}{ No } & Yes \\
\hline U.S. parties only & 1,460 & 651 & 2,111 & & 69.2 & 30.8 \\
Non-U.S. party, common-law country & 95 & 61 & 156 & 60.9 & 39.1 \\
Non-U.S. party, civil-law country & 48 & 25 & 73 & 65.8 & 34.2 \\
Total & 1,603 & 737 & 2,340 & & 68.5 & 31.5 \\
\hline
\end{tabular}

$\mathrm{SP}=$ specific performance.

SOURCE: SEC EDGAR database, LEXIS EDGAR PLUS database, Jan. 2002 to June 30, 2002 for all contract types other than mergers and Jan. 2002 to July 31, 2002 for merger contracts.

Table 6: Rate of Specific Performance Clauses, by Financial Contract Status

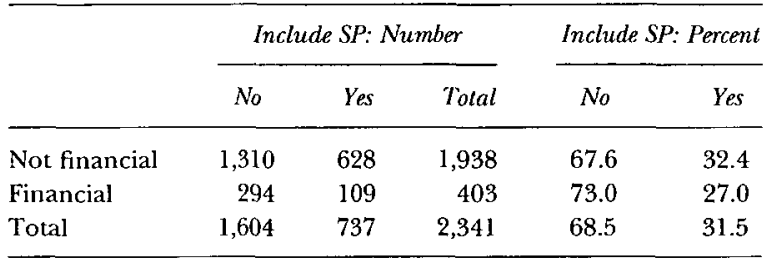

$\mathrm{SP}=$ specific performance.

Source: SEC EDGAR database, LEXIS EDGAR PLUS database, Jan. 2002 to June 30, 2002 for all contract types other than mergers and Jan. 2002 to July 31,2002 for merger contracts.

mance in contracts with a common-law country counterparty. ${ }^{96}$ Contracts that combine non-U.S. parties into a single group (Table 5's second and third rows) specified specific performance 37.6 percent of the time, which is significantly lower $(p=0.038)$ than the 30.8 percent rate at which U.S. parties' contracts specified specific performance.

Assessing the relation between financial contracts and specific performance requires categorizing contracts as financial or not financial. We start with a view of financial contracts that includes only the borrowing and repayment of money: bond indentures, credit commitments, and security agreements. In such contracts, lenders have generally performed and the measure of damages against borrowers is likely not materially different from what specific performance might require. Table 6 shows the rate of specific performance clauses in these lending contracts compared to other contracts.

As expected, lending agreements tend not to mention specific performance more than other contracts, and the rates statistically significantly differ $(p=0.039)$. If one expands the definition of financial contracts to include the asset-based lending agreements embodied in pooling and servicing contracts and their corresponding trust agreements

\footnotetext{
${ }^{96}$ The rate of specific performance is also not higher in contracts that choose a civil-law country as governing law.
} 
Table 7: Rate of Specific Performance Clauses, by Arbitration Clause Status

\begin{tabular}{lrrrrrr}
\hline & \multicolumn{2}{c}{ Include SP: Number } & & \multicolumn{2}{c}{ Include SP: Percent } \\
\cline { 2 - 3 } Contract & No & Yes & Total & & \multirow{2}{*}{ No } & Yes \\
\hline No arbitration clause & 1,455 & 615 & 2,070 & & 70.3 & 29.7 \\
Arbitration clause & 143 & 121 & 264 & & 54.2 & 45.8 \\
Total & 1,598 & 736 & 2,334 & & 68.5 & 31.5 \\
\hline
\end{tabular}

$\mathrm{SP}=$ specific performance.

Source: SEC EDGAR database, LEXIS EDGAR PLUS database, Jan. 2002 to June 30,2002 for all contract types other than mergers and Jan. 2002 to July 31,2002 for merger contracts.

based on their loan characteristics, ${ }^{97}$ the gap between financial and other contracts increases to 20.8 percent of financial contracts including specific performance compared to 35.4 percent of nonfinancial contracts $(p<0.001)$.

It has been asserted that "most arbitral awards contemplate money payments." ${ }^{98}$ As noted above, to the extent that parties expect an arbitral award to consist of money payments, ${ }^{99}$ the parties may anticipate and prefer that the remedy, if any, take the form of damages rather than specific performance. On the other hand, Table 2 shows that few contracts, only about 11 percent, depart from the default rule of access to a judicial forum in favor of a mandatory arbitration clause. As described above, parties who devote sufficient attention to contractual detail to forego the default judicial forum may be more likely at least to consider departing from the default damages rule and allow for specific performance. This association may swamp any tendency toward preferring money damages over specific performance.

Table 7 shows that contracts with arbitration clauses were in fact much more likely to contain specific performance clauses than are contracts without arbitration clauses. Contracts with arbitration clauses included specific performance clauses 45.8 percent of the time compared to 29.7 percent of contracts without arbitration clauses $(p<0.001)$. This is some evidence that parties willing to forego one default rule are more likely to forego another default rule.

One possible explanation is that this difference is driven by employment contracts, which tend to have the highest rates of arbitration clauses. ${ }^{100}$ Excluding employment contracts, however, does not narrow the gap in specific performance clause use. About 44

\footnotetext{
${ }^{97}$ See text accompanying note 76 supra.

${ }^{98}$ See Markovits, supra note 89 , at 479 .

${ }^{99} \mathrm{Id}$.
}

${ }^{100}$ Eisenberg \& Miller, The Flight from Arbitration, supra note 7, at 351 (showing employment contracts to have the highest rate of arbitration clauses). 
Table 8: Rate of Specific Performance Clauses, by Jury Trial Waiver Status

\begin{tabular}{lrrrrrr}
\hline & \multicolumn{2}{c}{ Include SP: Number } & & \multicolumn{2}{c}{ Include SP: Percent } \\
Contract & \multicolumn{1}{c}{ No } & Yes & Total & & No & Yes \\
\hline No jury trial waiver & 1,341 & 521 & 1,862 & & 72.0 & 28.0 \\
Jury trial waiver & 263 & 215 & 478 & & 55.0 & 45.0 \\
Total & 1,604 & 736 & 2,340 & & 68.5 & 31.5 \\
\hline
\end{tabular}

$\mathrm{SP}=$ specific performance.

SOURCE: SEC EDGAR database, LEXIS EDGAR PLUS database, Jan. 2002 to June 30, 2002 for all contract types other than mergers and Jan. 2002 to July 31,2002 for merger contracts.

percent of nonemployment contracts with arbitration clauses included specific performance clauses compared to 28.7 percent of nonemployment contracts without arbitration clauses. The gap hardly narrows and remains highly statistically significant $(p<0.001)$. Whatever the expected dominance of damages remedies in arbitration, parties preferred damages relatively less than specific performance in contracts that include arbitration.

Parties who opt out of jury trials promote the use of equitable remedies, which tend to be awarded by courts rather than by juries. That preference for equitable remedies may translate into greater use of specific performance clauses. In addition, as in the case of arbitration clauses, the great majority of contracts do not include jury trial waivers. Parties that devote sufficient attention to contractual detail to forego the default rule of jury trial availability may be more likely to depart from other default rules, including damages being preferred over specific performance. Table 8 shows that contracts with jury trial waivers were much more likely to contain specific performance clauses than are contracts without jury trial waivers clauses. Contracts with jury trial waivers included specific performance clauses 45.0 percent of the time compared to 28.0 percent of contracts without arbitration clauses $(p<0.001)$. This is additional evidence that parties willing to forego one default rule are more likely to forego another default rule.

Table 9 explores whether an association exists between contracting out of the default American Rule on attorney fees and contracting out of the default damages rule. Panel A reports results based on our prior coding of contract fee clauses as accepting or not accepting the default American Rule. ${ }^{101}$ It suggests a modest positive association, with parties who rejected the American Rule providing for specific performance in 32.8 percent of contracts compared to parties who accepted the American Rule accepting specific performance in 29.2 percent of contracts. The difference is marginally statistically significant $(p=0.070)$.

This association is stronger under an alternative view of coding underwriting contracts. Panel A of Table 9 treats standard underwriting as specifying the English Rule for attorney fees. Although we coded underwriting contracts as using the English Rule, the

\footnotetext{
${ }^{101}$ Eisenberg \& Miller, The English Versus the American Rule, supra note 7, at 370-72.
} 
Table 9: Rate of Specific Performance Clauses, by Fee Clause Status

\begin{tabular}{|c|c|c|c|c|c|}
\hline & \multicolumn{3}{|c|}{ Include SP: Number } & \multicolumn{2}{|c|}{ Include SP: Percent } \\
\hline & No & Yes & Total & No & Yes \\
\hline \multicolumn{6}{|c|}{ A. Original Coding of American Rule } \\
\hline Reject American Rule & 991 & 484 & 1,475 & 67.2 & 32.8 \\
\hline Accept American Rule & 613 & 253 & 866 & 70.8 & 29.2 \\
\hline Total & 1,604 & 737 & 2,341 & 68.5 & 31.5 \\
\hline \multicolumn{6}{|c|}{$\begin{array}{l}\text { B. Recharacterize Underwriting Contracts as American Rule } \\
\text { Contracts }\end{array}$} \\
\hline Reject American Rule & 677 & 482 & 1,159 & 58.4 & 41.6 \\
\hline Accept American Rule & 927 & 255 & 1,182 & 78.4 & 21.6 \\
\hline Total & 1,604 & 737 & 2,341 & 68.5 & 31.5 \\
\hline
\end{tabular}

$\mathrm{SP}=$ specific performance.

SourCE: SEC EDGAR database, LEXIS EDGAR PLUS database, Jan. 2002 to June 30, 2002 for all contract types other than mergers and Jan. 2002 to July 31,2002 for merger contracts.

standard fee clause pattern in underwriting contracts could also reasonably be coded as accepting the American Rule. We coded most underwriting contracts as adopting the English Rule because the contracts provide that the securities issuer will pay the underwriter's attorney fees if liability stems from issuer behavior and the underwriter will pay the issuer's fees if liability is based on underwriter behavior. ${ }^{102}$ These indemnity provisions at first seem closer to the English Rule than to the American Rule since parties agree to pay each other's' fees. And the indemnifiable circumstances covered by the underwriting contracts involve the most likely kind of lawsuit relating to the issuance of securities, a third-party action against the issuer and the underwriter. In actions between issuers and underwriters that do not involve third parties, however, standard underwriting agreements do not opt out of the American Rule. ${ }^{103}$ So, for example, if the securities issuer sues the underwriter for breaching its duty to deliver underwriting services, the American Rule applies and coding these contracts as accepting the American Rule is also reasonable. ${ }^{104}$

Panel B of Table 9 shows the results if one characterizes standard underwriting agreements as accepting the American Rule. It shows a much stronger association between rejecting the default fee rule and rejecting the default damages rule. Parties who rejected the American Rule provided for specific performance in 41.6 percent of contracts and

\footnotetext{
${ }^{102}$ See Samuel N. Allen, A Lawyer's Guide to the Operation of Underwriting Syndicates, 26 New Eng. L. Rev. 319 , 326-27 (1991) ("each of the underwriters severally indemnifies the issuer against liabilities arising out of material misrepresentations or omissions from the registration statement and prospectus, but only to the extent that those misrepresentations or omissions were made or omitted in reliance upon written information furnished to the issuer by the underwriters").
}

${ }^{103}$ Va. Elec. \& Power Co., Current Report (Form 8-K), at Ex. 1 9 (Jan. 29, 2002).

${ }^{104}$ Eisenberg \& Miller, The English Versus the American Rule, supra note 7, at 373. 
Table 10: Rate of Specific Performance Clauses, by Whether Litigation Forum was Specified

\begin{tabular}{lrrrrrr}
\hline & \multicolumn{2}{c}{ Include SP: } & Number & & \multicolumn{2}{c}{ Include SP: Percent } \\
Contract & No & Yes & Total & & No & Yes \\
\hline No forum specified & 1,095 & 349 & 1,444 & & 75.8 & 24.2 \\
Forum specified & 505 & 386 & 891 & & 56.7 & 43.3 \\
Total & 1,600 & 735 & 2,335 & & 68.5 & 31.5 \\
\hline
\end{tabular}

SP = specific performance.

SOURCE: SEC EDGAR database, LEXIS EDGAR PLUS database, Jan. 2002 to June 30,2002 for all contract types other than mergers and Jan. 2002 to July 31,2002 for merger contracts.

parties who accepted the American Rule provided for specific performance in only 21.6 percent of contracts. The difference is highly statistically significant $(p<0.001)$.

The presence of a litigation forum selection clause in a contract is another indication that the parties, or their attorneys, have thought through some of the issues concerning how the dispute will be litigated. In such a case, the parties may also be more likely to make a deliberate decision to opt out of the damages rule rather than doing nothing and allowing the default rule to govern. Table 10 shows the relation between contracts that specified a litigation forum and contracts that provided for specific performance. Parties who specified a litigation forum provided for specific performance in 43.3 percent of contracts and parties who did not specify a litigation forum provided for specific performance in only 24.2 percent of contracts. The difference is highly statistically significant $(p<0.001)$.

We further explore the relation between specifying a litigation forum and specifying specific performance by focusing on the two states most often specified as litigation venues, New York and Delaware. We suggested above that confidence in those states' court systems might induce parties to accept the courts' determination of remedies without the need for specifying specific performance. Table 11 explores this suggestion. Contrary to our suggestion, contracts specifying Delaware or New York as litigation locales had higher rates of specific performance clause use than did contracts that did not specify a litigation forum. Whatever faith parties have in Delaware and New York courts does not translate into greater willingness to invest those courts with more remedial discretion by remaining contractually silent about specific performance.

Table 11's results for Delaware and New York are noteworthy given the common claim that Delaware's courts' expertise and predictability help attract legal business. ${ }^{105} \mathrm{~A}$ substantial difference in specific performance clause use emerged between Delaware forum contracts and New York forum contracts. Delaware forum contracts included specific performance clauses 71.7 percent of the time; New York forum contracts included specific performance clauses at about half that rate, 36.0 percent of the time, a highly statistically

\footnotetext{
${ }^{105}$ E.g., Eisenberg \& Miller, The Flight to New York, supra note 7, at 1480 (noting evidence of faith in Delaware courts).
} 
Table 11: Rate of Specific Performance Clauses, by Litigation Forum Choice

\begin{tabular}{|c|c|c|c|c|c|}
\hline & \multicolumn{3}{|c|}{ Include SP: Number } & \multicolumn{2}{|c|}{ Include SP: Percent } \\
\hline & No & Yes & Total & No & Yes \\
\hline DE & 28 & 71 & 99 & 28.3 & 71.7 \\
\hline NY & 249 & 140 & 389 & 64.0 & 36.0 \\
\hline Other & 246 & 182 & 428 & 57.5 & 42.5 \\
\hline No forum specified & 1,081 & 344 & 1,425 & 75.9 & 24.1 \\
\hline Total & 1,604 & 737 & 2,341 & 68.5 & 31.5 \\
\hline
\end{tabular}

$\mathrm{SP}=$ specific performance.

SOURCE: SEC EDGAR database, LEXIS EDGAR PLUS database, Jan. 2002 to June 30, 2002 for all contract types other than mergers and Jan. 2002 to July 31, 2002 for merger contracts.

significant difference $(p<0.001)$. One possible explanation for this difference is the varying distributions of contract types across the two states. However, controlling for contract type does not eliminate the difference. For each of the three contract types for which Delaware or New York was the specified litigation forum, and for which both Delaware and New York had at least 10 contracts-assets sales/purchases, mergers, and securities purchaseDelaware forum contracts had higher rates of specific performance clause use than New York forum contracts. This subsample of three contract types includes 91 Delaware contracts, 190 New York contracts, and the difference in specific performance clause use (74.7 percent for Delaware; 56.3 percent for New York) is significant at $p=0.003$.

\section{B. Accounting for Multiple Explanatory Variables}

Because multiple influences may be associated with contracts containing specific performance clauses, regression analysis is useful in assessing whether bivariate results persist when explanatory factors are taken into account simultaneously. Since the outcome variable of interest, inclusion of a specific performance clause, is dichotomous, we employ logistic regression. ${ }^{106}$

Table 12 reports the regression results. All six models include dummy variables representing the legal system of the counterparty to the reporting company. For this factor, contracts involving a non-U.S. party that is from a civil-law country is the reference category. Models (1) and (4) use dummy variables for contract types, with merger contracts as the reference category. Models (2), (3), (5), and (6) replace the individual contract types with variables that represent contract characteristics, dummy variables for relational contracts and for financial contracts. These variables cannot be included in models with dummy variables for contract types due to collinearity because the contract characteristic variables are constructed from the contract type variables. Model (3) differs from Model (2), and Model (6) differs from Model (5), in the use of use the alternate coding of financial

${ }^{106}$ E.g., A. Colin Cameron \& Pravin K. Trivedi, Microeconomics Using Stata 459 (rev. ed. 2010 ). 
Table 12: Logistic Regression Models of Presence of Specific Performance Clause

\begin{tabular}{|c|c|c|c|c|c|c|}
\hline & \multicolumn{6}{|c|}{ Dependent Variable $=$ Specific Performance Clause Included in Contract } \\
\hline & (1) & (2) & (3) & (4) & (5) & (6) \\
\hline Asset sale/purchase & $\begin{array}{l}-0.051^{* *} \\
(0.023)\end{array}$ & & & $\begin{array}{c}-0.031 \\
(0.025)\end{array}$ & & \\
\hline Bond indentures & $\begin{array}{l}-0.054^{* *} \\
(0.027)\end{array}$ & & & $\begin{array}{c}0.005 \\
(0.035)\end{array}$ & & \\
\hline Gredit commitments & $\begin{array}{l}-0.202^{* * * *} \\
(0.020)\end{array}$ & & & $\begin{array}{l}-0.206^{* * *} \\
(0.020)\end{array}$ & & \\
\hline Employment contracts & $\begin{array}{c}0.031 \\
(0.042)\end{array}$ & & & $\begin{array}{c}0.081^{*} \\
(0.049)\end{array}$ & & \\
\hline Licensing & $\begin{array}{l}-0.105^{* * *} \\
(0.032)\end{array}$ & & & $\begin{array}{c}-0.080 * * \\
(0.037)\end{array}$ & & \\
\hline Pooling service & $\begin{array}{l}-0.211 * * * \\
(0.022)\end{array}$ & & & $\begin{array}{l}-0.192^{* * *} \\
(0.024)\end{array}$ & & \\
\hline Security agreements & $\begin{array}{l}-0.090 * * \\
(0.040)\end{array}$ & & & $\begin{array}{c}-0.086^{* *} \\
(0.040)\end{array}$ & & \\
\hline Securities purchase & $\begin{array}{l}-0.104^{* * *} \\
(0.020)\end{array}$ & & & $\begin{array}{l}-0.104 * * * \\
(0.020)\end{array}$ & & \\
\hline Settlements & $\begin{array}{l}-0.141 * * * \\
(0.025)\end{array}$ & & & $\begin{array}{l}-0.133^{* * *} \\
(0.026)\end{array}$ & & \\
\hline Trust agreements & $\begin{array}{l}-0.201 * * * \\
(0.022)\end{array}$ & & & $\begin{array}{l}-0.190^{* * *} \\
(0.025)\end{array}$ & & \\
\hline Underwriting & $\begin{array}{l}-0.367^{* * * *} \\
(0.014)\end{array}$ & & & $\begin{array}{l}-0.355^{* * *} \\
(0.015)\end{array}$ & & \\
\hline U.S. legal system & $\begin{array}{c}0.026 \\
(0.043)\end{array}$ & $\begin{array}{c}-0.017 \\
(0.057)\end{array}$ & $\begin{array}{c}-0.003 \\
(0.056)\end{array}$ & $\begin{array}{c}0.028 \\
(0.042)\end{array}$ & $\begin{array}{c}-0.003 \\
(0.056)\end{array}$ & $\begin{array}{c}0.006 \\
(0.055)\end{array}$ \\
\hline Non-U.S. common law & $\begin{array}{c}0.055 \\
(0.062)\end{array}$ & $\begin{array}{c}0.048 \\
(0.069)\end{array}$ & $\begin{array}{c}0.056 \\
(0.069)\end{array}$ & $\begin{array}{c}0.050 \\
(0.060)\end{array}$ & $\begin{array}{c}0.048 \\
(0.069)\end{array}$ & $\begin{array}{c}0.053 \\
(0.069)\end{array}$ \\
\hline Relational contract & & $\begin{array}{l}-0.106^{* * * *} \\
(0.029)\end{array}$ & $\begin{array}{c}-0.045 \\
(0.036)\end{array}$ & & $\begin{array}{l}-0.098^{* * *} \\
(0.031)\end{array}$ & $\begin{array}{c}-0.051 \\
(0.040)\end{array}$ \\
\hline Financial contract & & $\begin{array}{c}-0.011 \\
(0.034)\end{array}$ & & & $\begin{array}{c}-0.006 \\
(0.037)\end{array}$ & \\
\hline $\begin{array}{l}\text { Financial contract } \\
\text { (including pooling } \\
\text { servicing agreements) }\end{array}$ & & & $\begin{array}{l}-0.107^{* * *} \\
(0.036)\end{array}$ & & & $\begin{array}{c}-0.080^{* *} \\
(0.041)\end{array}$ \\
\hline DE forum & & & & $\begin{array}{l}0.362 * * * \\
(0.063)\end{array}$ & $\begin{array}{l}0.459 * * * \\
-0.045\end{array}$ & $\begin{array}{l}0.452^{* * *} \\
-0.046\end{array}$ \\
\hline $\mathrm{NY}$ forum & & & & $\begin{array}{l}0.179 * * * \\
-0.035\end{array}$ & $\begin{array}{l}0.128 * * * \\
-0.032\end{array}$ & $\begin{array}{l}0.127 * * * \\
-0.032\end{array}$ \\
\hline Other forum & & & & $\begin{array}{l}0.116^{* * * *} \\
-0.028\end{array}$ & $\begin{array}{l}0.192^{* * *} \\
-0.03\end{array}$ & $\begin{array}{l}0.184^{* * * *} \\
-0.03\end{array}$ \\
\hline Observations & 2,340 & 2,295 & 2,295 & 2,340 & 2,295 & 2,295 \\
\hline Pseudo $r^{2}$ & 0.173 & 0.010 & 0.0156 & 0.202 & 0.052 & 0.054 \\
\hline
\end{tabular}

NoTE: The table shows the marginal effects of the explanatory variables on whether a specific performance clause was included in a contract. Standard errors clustered on reporting company are reported. $* p<0.1 ; * * p<0.05$; $* * * p<0.01$.

SouRcE: SEC EDGAR database, LEXIS EDGAR PLUS database, Jan. 2002 to June 30, 2002 for all con tract types other than mergers and Jan. 2002 to July 31, 2002 for merger contracts. 
contracts. Note that results for two different financial contract dummy variables are reported. It treats asset-based lending agreements documented by pooling and servicing contracts and their corresponding trust agreements as financial contracts. ${ }^{107}$ Models (4), (5), and (6) differ from Models (1), (2), and (3) by including dummy variables for the litigation forum specified, with no litigation forum specified being the reference category. Our goal in including the litigation forum dummy variables is to assess whether the contract type results are sensitive to including litigation forum variables since Tables 10 and 11 indicate that the absence of a litigation forum has a strong association with contracts' treatment of the default damages rule. ${ }^{108}$

Table 12 reports the marginal effects of the explanatory variables on the outcome variable. The marginal effects are interpretable as the change in the probability of a litigation cost denial given a one-unit change in an explanatory variable. For categorical explanatory variables, this change in probability is in comparison to a reference categorythat is, a value of the explanatory variable against which changes in the outcome probability are measured.

The reference category for contract types is mergers. This means that the marginal effects for the other contract types in Models (1) and (3) indicate how much more or less likely a specific performance clause becomes compared to the baseline case of a merger contract. No litigation forum being specified is the reference category for the litigation forum dummy variables in Models (4), (5), and (6).

The two models, (1) and (4), in Table 12 that include dummy variables for contract type show the marginal effects for those variables to be largely negative and statistically significant. This suggests that the reference category, mergers, is more likely to include specific performance clauses than most other contract types. In Model (1), employment contracts are the only contract type with a positive marginal effect, indicating a higher probability of a specific performance clause, but the effect is small and does not significantly differ from mergers. Credit commitments are about 20 percent less likely than merger agreements to include a specific performance clause. Underwriting agreements are much less likely to include express specific performance clauses but recall that they could reasonably be characterized as including a form of specific performance. ${ }^{109}$ The model's results are consistent with Table 3's nonregression rates of specific performance clause use, but we now control for the legal system of the counterparties to the contract. The legal system variables themselves are of small marginal effect and statistically insignificant. This largely confirms Table 5, which shows small differences in specific performance clause use across

\footnotetext{
${ }^{107}$ See text accompanying note 76 supra.

${ }^{108}$ We forego reporting models that include dummy variables for other default dispute resolution clauses (attorney fee clauses, arbitration clauses, and jury trial waiver clauses) due to likely endogeneity or reverse causation. These models do not materially change the central results in Table 12. But these models are questionable because they raise a problem similar to that of including the litigation forum dummy variables. Variables representing these other dispute resolution clauses may lead, follow, or be simultaneous with the decision to contract for specific performance. We instead use the CART analysis below to suggest their role in explaining the pattern of specific performance clause use.
}

${ }^{109}$ See text accompanying notes $78-80$ supra. 
legal systems of counterparties, and suggests that any significant difference in that table was due to not controlling for type of contract.

Model (4) of Table 12 retains the individual contract type dummy variables and adds controls for clauses that specify a legal forum. Comparing it to Model (1), the marginal effect for asset sale/purchase contracts decreases slightly relative to mergers and becomes insignificant. The coefficient for employment contracts increases by 5 percent and becomes marginally statistically significant. The biggest change is with respect to bond indentures where, compared to Model (1), the marginal effect changes direction and becomes statistically significant. This change is attributable to the gap between specific performance clause use in merger contracts and bond indentures being in a different direction and substantially narrower ( 59 percent vs. 38 percent) in contracts that do not specify a litigation forum than it is (52 percent vs. 100 percent) in contracts that do specify a litigation forum. With that qualification, Table 12's results are again consistent with those in Tables 3 and 5.

The results for Models (2), (3), (5), and (6) of Table 12 are sensitive to what contract types are coded as financial. If one does not characterize pooling and servicing agreements and their trust agreements as financial contracts, as is done in Models (2) and (5), then relational contract status is negatively associated with whether one observes a specific performance clause. But this result changes if one recasts pooling and servicing agreements and their trust agreements as financial contracts, as is done in Models (3) and (6). Then relational contract status is not statistically significant; only financial contract status is statistically significant. These models mainly confirm the unimportance of the legal system variables using the alternative aggregated coding of contract types.

Models (4), (5), and (6) of Table 12 show litigation forum dummy variables to be highly statistically significant, which is consistent with the results in Tables 10 and 11. This set of dummy variables, however, likely suffers from endogeneity or two-way causation because of the association between inclusion of one nondefault clause in a contract and inclusion of another, as shown in Section VI. ${ }^{110}$ Dispute resolution clauses' presence in contracts are likely associated with one another. For example, the models assess the influence of litigation forum clause treatment on the presence of a specific performance clause. However, the presence of a specific performance clause might also influence the presence of a litigation forum clause, or the two may be simultaneously influenced by common factors. The models nevertheless provide some evidence that the principal results in Models (1) to (3) persist after controlling for the contracts' treatment of litigation forum.

As a check on our regression results, we constructed a classification and regression tree (CART). CART analysis helps explore how decisions branch at what are believed to be relevant nodes in the analysis (i.e., at the explanatory variables) ${ }^{111}$ Each node in a decision

\footnotetext{
${ }^{110} \mathrm{~A}$ complete model of dispute resolution clause inclusion likely would require a simultaneous equations model and allow for causation to flow in more than one direction across dispute resolution clauses. We lack a substantial set of explanatory variables that make estimating such models feasible.
}

${ }^{11}$ See generally Leo Breiman, Jerome H. Friedman, Charles J. Stone \& Richard A. Olshen, Classification and Regression Trees (1984); Jonathan P. Kastellec, The Statistical Analysis of Judicial Decision and Legal Rules with Classification Trees, 7 J. Empirical Legal Stud. 202 (2010). 
Figure 1: Classification and regression tree for specific performance clauses.

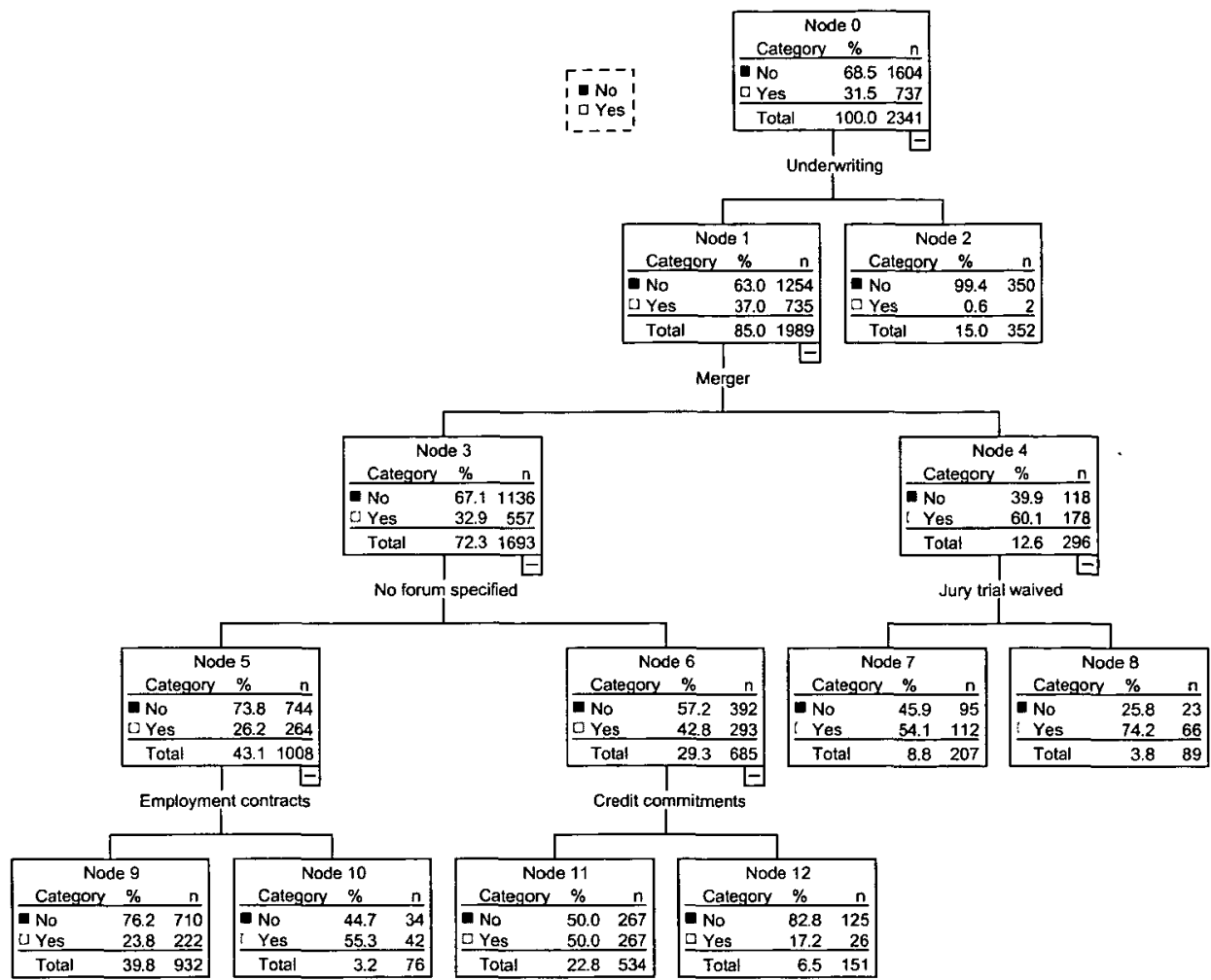

NotE: This classification tree provides a nonparametric analysis of the relation between hypothesized factors and the dependent variable, the presence of a specific performance clause, in 2,341 contracts. The tree confirms the importance of contract type and the association of the presence of a specific performance clause with the presence of other dispute resolution clauses.

SOURCE: SEC EDGAR database, LEXIS EDGAR PLUS database, Jan. 2002 to June 30, 2002 for all contract types other than mergers and Jan. 2002 to July 31, 2002 for merger contracts.

tree is split into two groups, and the data are then partitioned into those groups to process the data farther down the tree. This binary partitioning process is then repeated, with child nodes generating their own subnodes. CART is a useful check on results obtained by logistic regression because it is nonparametric and therefore does not depend on assumptions underlying regression models.

Figure 1 presents a CART for our data. Although space constraints prevent presenting a CART that shows the relation to specific performance of less influential variables, Figure 1 confirms our evidence of strong associations between the presence of a specific performance clause (Node 0 ) and contract type and the treatment of other default dispute resolution clauses. The dummy variable for underwriting is the highest branch (Nodes 1 and 2) in the classification tree, with Node 2 showing the rate of specific performance clauses in underwriting contracts and Node 1 showing the rate in other contracts. These contracts' high level in the CART is not surprising given our coding of specific performance 
clauses as almost never being present in underwriting agreements. In light of our discussion of reasonable alternative coding of underwriting agreements almost all containing implicit specific performance clauses, it is worth noting that underwriting agreements would retain their prominence in a CART that coded them as including specific performance. The dummy variable for mergers is the next highest branch in the CART (Nodes 3 and 4), with Node 4 showing the rate of specific performance clauses in merger contracts and Node 3 showing the rate in other contracts (excluding underwriting contracts, which are accounted for in a higher set of nodes). This suggests that large public firms have a strong ex ante demand for specific performance in merger agreements. Importantly, the merger node is higher in the CART than are any of the dispute resolution clause variables. This can be interpreted as meaning that the desire for specific performance in merger contracts is likely not largely a consequence of the treatment of other dispute resolution clauses in such contracts. This is evidence that it is the nature of merger transactions that drives the demand for specific performance clauses.

The two next most prominent branches (Nodes $5,6,7$, and 8 ) suggest that treatment of other dispute resolution clauses-no litigation forum being specified and jury trial being waived-are strongly associated with the presence of specific performance clauses. Below these dispute resolution clause branches, contract type again becomes important, with employment contracts showing high use of specific performance clauses and credit commitments rarely using them. Other variables in the data are less prominent in explaining the pattern of specific performance clause use. These lower branches in the CART are not shown in Figure 1.

CART analysis confirms the associations detected in the bivariate and regression analyses, highlights the importance of case type and litigation forum treatment in explaining the pattern of specific performance use, and provides a useful visualization of the data.

\section{Discussion}

We further discuss two classes of results. One class is specific to this article's codification of specific performance clauses. A prominent theme of our codification is variation. Variation exists both in the rate at which specific performance is mentioned by type of contract and in the reasons why contracts mention specific performance. The second class of results incorporates our prior findings with respect to rates of opting out of four other default rules in the contracts: arbitration clauses, jury trial waiver clauses, litigation forum clauses, and attorney fee clauses. Understanding rates of opting out of one default rule can help explain rates of opting out of other default rules.

\section{A. Implications of Variation}

The prominence of variation has implications for theories of contractual remedies and suggests limits on what our somewhat mechanical coding of contract terms can reveal. 
Variation in specific performance specification rates has implications for the theoretical debate over justifications for the subordination of specific performance. ${ }^{112}$ One theory argues for maintaining the default subordination approach to specific performance across all corporate contracts"113 on the ground that "a promisor who fails to deliver the promised goods or services but instead transfers the gain to her promisee performs rather than breaches."114

In one perspective, our results support theoretical arguments favoring the default damages rule. That most of the contracts in our sample do not opt out of contract damages suggests that most contracting parties are not so dissatisfied with the traditional rule that they elected to include a specific opt-out clause in their contract. Sophisticated parties to the contracts in the sample accepting the default damages rule may be taken as some vindication of theories favoring the default rule. A qualification on this inference is necessary, however. The failure to opt out of the traditional rule does not necessarily indicate that the rule is efficient or theoretically correct. Although the decision to opt out of the traditional rule indicates a degree of affirmative intentionality, the failure to opt out of a background rule may or may not be a considered decision; it is also possible that the parties simply did not think about the question. ${ }^{15}$

More importantly, many of the contracts do in fact reject the default rule, and a majority do so for two contract types, merger agreements and employment agreements, as shown in Table 3 . The varying rates of contracting for specific performance liability suggest that ubiquitous acceptance of the default damages rule does not capture the reality of the behavior of sophisticated economic actors, and may be inefficient for some contract categories, just as it seems inconsistent with experimental results about preferences for specific performance. ${ }^{116}$ As Table 3 shows, over half the merger agreements provided for specific performance, and more likely would accept specific performance as a term if it were the default rule. The default damages liability rule required parties to most merger agreements to raise and negotiate the issue, at added cost and reduced efficiency.

Nor does regarding the transfer of gain being regarded ex ante as performance ring true in the merger context. The acquiring company wants the assets in the expectation that gains are to be had, but the ability persuasively to quantify that gain must often be questionable, which must be at least part of the reason why parties so often expend the

\footnotetext{
${ }^{112}$ Compare, e.g., Markovits \& Schwartz, The Myth of Efficient Breach, supra note 11, with Klass, supra note 43.

${ }^{118}$ Id. at 1943 ("contract law should retain its traditional commitment to vindicating the promisee's expectation interest and should protect this interest by a liability rule").

${ }^{114}$ Id. at 1948 .

${ }^{115}$ Several studies of contracting behavior suggest that parties often fail to opt out of inefficient background rules. See Omri Ben-Shahar \& John A.E. Pottow, On the Stickiness of Default Rules, 33 Fla. St. U. L. Rev. 651 (2006); Lisa Bernstein, Comment, Social Norms and Default Rules Analysis, 3 S. Cal. Interdisciplinary L. Rev. 59, 71-72 (1993); Russell Korobkin, The Status Quo Bias and Contract Default Rules, 83 Comell L. Rev. 608 (1998).
}

${ }^{116}$ For efforts to distinguish a series of experimental results showing a preference for specific performance, see Markovits \& Schwartz, supra note 11, at 1954-55 n.32. 
effort to provide for specific performance. The relatively high rate of specific performance clauses in a class of contracts closely related to mergers, asset sale agreements (45.1 percent as shown in Table 3), likely results from parties' similar concerns about the difficulty of valuing the lost gain in the event of failure to deliver assets. One traditional alternative to specific performance as a remedy, a different contract price, also is not obviously an adequate alternative in this context. The optimal price adjustment likely suffers from the same uncertainty as does quantifying the gain from the transaction.

This is not to say that performance and transfer of gain are always far from equivalent. The equivalence between performance and transfer of gain is more persuasive in the context of financial agreements, where the gain is relatively easy to quantify. This provides support for the default damages rule, but only in a subset of firms' agreements. The parties' contractual behavior in our sample is consistent with damages being the default rule in this class of agreements, as we hypothesized and as Table 6 confirms.

Variation in the reasons why specific performance is mentioned also suggests a limitation of our approach in coding contracts as either endorsing or not mentioning specific performance. Substantial variation exists in the reasons why specific performance clauses are or are not used. As noted above, some contracts may not mention specific performance because the parties assume it will be available when appropriate. Others mention specific performance seemingly to negate any inference that other terms in a contract might be interpreted to foreclose or limit specific performance. ${ }^{117}$ Other provisions supplementing default damages rules may not address the general availability of specific performance but instead focus on specific contract defaults. A Fortune 500 company agreement with its chief executive officer addressed remedies for breach of the officer's contractual covenants not to compete. "Executive agrees that the Company's remedies at law would be inadequate in the event of a breach or threatened breach of Section 8 of this Agreement; accordingly, the Company shall be entitled, in addition to its rights at law, to seek an injunction or other equitable relief without the need to post a bond." 118 Still other contracts set forth specific terms that promote specific performance without referring to it as such, as in the case of underwriting agreements requiring nondefaulting underwriters to purchase securities allocated to a defaulting underwriter. ${ }^{119}$

\footnotetext{
${ }^{117}$ Asset Purchase Agreement dated as of Oct. 17, 2001 between Imation and KPG $\$ 10.02(\mathrm{c})$.
}

${ }^{118}$ Employment Agreement, dated as of Feb. 18, 2002, by and between Honeywell International Inc. ("Honeywell"), a Delaware corporation (together with its successors and assigns pernitted under this Agreement, the "Company"), and David M. Cote ("Executive") $\$ 8$.

${ }^{119}$ See, e.g., Northwestern Corporation, Form 8-K, Exh.1.1: 8.10\% Trust Preferred Securities Underwriting Agreement $\$ 10$, at 24, Jan. 24, 2002, filed Jan. 31, 2002, SEC File No.: 001-10499, Accession No.: 0000912057-02-003623; Bank of America Corporation, Form 8-K, Exh.1.1: BAC Capital Trust II 7\% Capital Securities (Liquidation Amount of $\$ 25$ per Capital Security) Underwriting Agreement \$8, at. 23, Jan. 24, 2002, filed Jan. 31, 2002, SEC File No.: 001-06523, Accession No: 0000895527-02-000010. Both underwriting agreements contain the following or similar language:

If one or more of the Underwriters shall fail at Closing Time or the relevant Date of Delivery, as the case may be, to purchase the Preferred Securities which it or they are obligated to purchase under this Agreement (the "Defaulted Securities"), the Representatives shall have the right, within 24 hours thereafter, to make 
This richness of terms relating to specific performance poses challenges to coding schemes that do not distinguish among the reasons.

\section{B. Associations with Other Default Dispute Resolution Rules}

This study's specific performance clause results, when combined with our earlier studies of arbitration clauses, jury trial waiver clauses, litigation forum clauses, and attorney fee clauses, ${ }^{120}$ yields information about acceptance or rejection of five default dispute resolution rules. A natural question is the degree of association among default clause rejection rates for the five rules.

The dispute resolution clauses relating to default rules cluster logically into two groups. One group-arbitration clauses, jury trial waiver clauses, and litigation forum clauses-addresses forum and adjudicator issues. The second group-attorney fee clauses and specific performance clauses-focuses not on forum but on the substantive remedies available under the contracts. One might expect the presence of forum and adjudicator clauses to be strongly associated with one another and the presence of the substantive clauses to be associated with one another. More generally, do default dispute resolution rules tend to be rejected individually or in groups?

Table 13 reports a measure of association, the phi $(\varphi)$ coefficient, for each of 10 dispute resolution clause pairs. The phi coefficient is a measure of association between two categorical variables. In the case of a $2 \times 2$ table, which each cell in Table 13 summarizes, $\varphi$ is equivalent to the correlation coefficient. For each of these coefficients, however, caution is needed in interpreting the level of the coefficient. Neither $\varphi$ nor the correlation coefficient can achieve the maximum value of 1 in a $2 \times 2$ table with categorical data. The more useful information in the table is thus the comparative size of the coefficients, rather than their absolute levels. The second entry in each cell is the $p$ value measure of statistical significance for the underlying $2 \times 2$ table.

Each entry in Table 13 summarizes the contents of a $2 \times 2$ table. For example, the table's first cell, in which arbitration clauses are the row variable and specific performance clauses are the column variable, provides the measure of association for a $2 \times 2$ table in which the two rows are the presence or absence of an arbitration clause and the two columns are the presence or absence of a specific performance clause. For this combination of clauses, $\varphi=0.11$, significant at $p<0.001$. The table's last row provides an additional

arrangements for one or more of the non-defaulting Underwriters, or any other underwriters, to purchase all, but not less than all, of the Defaulted Securities....

Variations on this language appear in many underwriting agreements. Gulf Power Company, Form 8-K, Exh.1.1: $\$ 45,000,000$ Series E $6.00 \%$ Senior Notes Underwriting Agreement $\$ 10$, Jan. 18, 2002, filed Jan. 30, 2002, SEC File No.: 000-02429, Accession No.: 0000044545-02-000002 (obligating nondefaulting underwriters to purchase defaulted securities); Ford Motor Company, Form 8-K, Exh.1.1: Ford Motor Company Capital Trust II, _\% Cumulative Convertible Trust Preferred Securities (Liquidation Preference $\$ 50$ per Preferred Security) [Form of Underwriting Agreement] \$ 10, at 22, _, 2002, filed Jan. 30, 2002, SEC File No.: 001-03950, Accession No.: 0000950124-02-000164 (obligating nondefaulting underwriters to purchase defaulted securities).

${ }^{120}$ See sources cited in note 7 supra. 
Table 13: Associations Among Dispute Resolution Clauses

\begin{tabular}{|c|c|c|c|c|}
\hline & Specific Performance & Arbitration Clause & Jury Trial Waived & $\begin{array}{c}\text { Specify Litigation } \\
\text { Forum }\end{array}$ \\
\hline Arbitration clause & $\Phi=0.11 ; p<0.001$ & & & \\
\hline Jury trial waived & $\Phi=0.15 ; p<0.001$ & $\Phi=0.03 ; p=0.133$ & & \\
\hline Specify litigation forum & $\boldsymbol{\Phi}=0.20 ; p<0.001$ & $\Phi=0.04 ; p=0.058$ & $\Phi=0.43 ; p<0.001$ & \\
\hline Reject American Rule & $\Phi=0.04 ; p=0.070$ & $\Phi=0.06 ; p=0.008$ & $\Phi=0.02 ; p=0.406$ & $\Phi=0.04 ; p=0.077$ \\
\hline $\begin{array}{l}\text { Reject American Rule } \\
\text { (treating underwriting } \\
\text { as American Rule) }\end{array}$ & $\Phi=0.22 ; p<0.001$ & $\Phi=0.15 ; p<0.001$ & $\Phi=0.12 ; p<0.001$ & $\Phi=0.13 ; p=<0.001$ \\
\hline
\end{tabular}

Sources: Eisenberg \& Miller, The Flight from Arbitration, supra note 7, at 351 (tbl. 2); Eisenberg \& Miller, The English vs. the American Rule, supra note 7, at 352 (tbl. 2); Eisenberg \& Miller, Do Juries Add Value? supra note 7, at 553 (tbl. 2); SEC EDGAR database, LEXIS EDGAR PLUS database, Jan. 2002 to June 30, 2002 for all contract types other than mergers and Jan. 2002 to July 31, 2002 for merger contracts.

comparison for the recharacterized treatment of the American Rule on attorney fees, modified in the case of underwriting contracts, as described in Section V.

As described in Section V, Table 13's first column shows that the presence of specific performance clauses is associated with rejecting the four other dispute resolution clauses, and this relation is highly statistically significant for all combinations if the modified American Rule coding for underwriting contracts is used. Using that modified coding, all but two associations among clauses in the table are highly statistically significant. The single strongest association in the table is between the presence of a litigation forum clause and waiver of jury trial. This is likely because parties who focus on a litigation forum likely also focus on the adjudicator in that forum.

The exceptions are for the relation between arbitration clauses and (1) jury trial waiver clauses and (2) litigation forum clauses. These weak associations are likely because the presence of an arbitration clause largely moots the issues of jury trial and litigation forum. Juries are not available in arbitration and a litigation forum is less important than the details of the arbitration mechanism. So the patterns of significant associations between rejection of default rules is reasonably consistent and the exceptions are readily explicable.

\section{Conclusion}

Specific performance clauses are a rich source of contract theory, adjudicated cases, and speculation. Prior studies have not focused on the rates of such clauses' use, much less on the implications of the rates of use for theory. Our data provide modest endorsement of specific performance being subordinate to the default damages rule because a majority of contracts accept the default rule, at least if silence is read as approval. However, the data also suggest that inferring endorsement across a broad range of contract types is unwarranted. Sufficient variation in opting into specific performance across contract types suggests that theories of contractual remedies should expressly account for contract type variation. High rates of specific performance use in the area of corporate combinations 
through merger or asset sales, and inclusion of specific performance in at least some contracts of every type, suggest that the real world of sophisticated corporate contracting is more complex than can be captured by existing theories of contractual remedies.

Variation of specific performance use by contract type is in one sense consistent with the common-law treatment of specific performance, which classically distinguished between real estate contracts and other contracts. ${ }^{121}$ Our data do not identify real estate transactions and the distinction is said to be fading. ${ }^{122}$ Nevertheless, the modern business acquisition, developed well after the common law's distinctive treatment of land contracts, might be analogized to acquiring unique assets, just as each land transaction was regarded as unique. Our data thus support, consistently with the common law, the wisdom and efficiency of differentiating by contract type in the area of specific performance.

\footnotetext{
${ }^{121}$ E.g., Kitchen v. Herring, 42 N.C. 190 (1851) (refusing to extend specific performance to a contract relating to timber because it differed from land).

${ }^{122}$ E.g., Farnsworth, supra note 56 , at 746-47.
} 